\title{
The central mechanism underlying hypertension: a review of the roles of sodium ions, epithelial sodium channels, the renin-angiotensin-aldosterone system, oxidative stress and endogenous digitalis in the brain
}

\begin{abstract}
Hakuo Takahashi ${ }^{1}$, Masamichi Yoshika ${ }^{1}$, Yutaka Komiyama ${ }^{1}$ and Masato Nishimura ${ }^{1,2}$
The central nervous system has a key role in regulating the circulatory system by modulating the sympathetic and parasympathetic nervous systems, pituitary hormone release, and the baroreceptor reflex. Digoxin- and ouabain-like immunoreactive materials were found $>\mathbf{2 0}$ years ago in the hypothalamic nuclei. These factors appeared to localize to the paraventricular and supraoptic nuclei and the nerve fibers at the circumventricular organs and supposed to affect electrolyte balance and blood pressure. The turnover rate of these materials increases with increasing sodium intake. As intracerebroventricular injection of ouabain increases blood pressure via sympathetic activation, an endogenous digitalis-like factor (EDLF) was thought to regulate cardiovascular system-related functions in the brain, particularly after sodium loading. Experiments conducted mainly in rats revealed that the mechanism of action of ouabain in the brain involves sodium ions, epithelial sodium channels (ENaCs) and the renin-angiotensin-aldosterone system (RAAS), all of which are affected by sodium loading. Rats fed a high-sodium diet develop elevated sodium levels in their cerebrospinal fluid, which activates ENaCs. Activated ENaCs and/or increased intracellular sodium in neurons activate the RAAS; this releases EDLF in the brain, activating the sympathetic nervous system. The RAAS promotes oxidative stress in the brain, further activating the RAAS and augmenting sympathetic outflow. Angiotensin II and aldosterone of peripheral origin act in the brain to activate this cascade, increasing sympathetic outflow and leading to hypertension. Thus, the brain $\mathrm{Na}^{+}-\mathrm{ENaC}-\mathrm{RAAS}-\mathrm{EDLF}$ axis activates sympathetic outflow and has a crucial role in essential and secondary hypertension. This report provides an overview of the central mechanism underlying hypertension and discusses the use of antihypertensive agents.
\end{abstract} Hypertension Research (2011) 34, 1147-1160; doi:10.1038/hr.2011.105; published online 4 August 2011

Keywords: hypothalamus; mineralocorticoid receptor; ouabain; renin-angiotensin-aldosterone system; sympathetic nervous activity

\section{INTRODUCTION}

Epidemiological studies show that hypertension onset is strongly associated with salt consumption: ${ }^{1-5}$ there is a close relationship between average sodium salt intake and the incidence of hypertension, ${ }^{6,7}$ and restriction of sodium intake substantially decreases blood pressure. ${ }^{8,9}$ When sodium salt is loaded, factors that inhibit $\mathrm{Na}^{+}$, $\mathrm{K}^{+}$-ATPase activity increase in the circulating blood ${ }^{10}$ and in some tissues. ${ }^{11}$ As inhibitors of $\mathrm{Na}^{+}, \mathrm{K}^{+}$-ATPase activity were identified as digitalis glycosides, they are termed 'endogenous digitalis-like factors' (EDLFs). ${ }^{12-15}$ Despite extensive efforts over 40 years, the salt-EDLFhypertension cascade has been elucidated only recently. Interestingly, there are several EDLFs in the circulating blood, even in subjects who have never ingested any digitalis glycoside either as medicine or in food containing digitalis-like substances. ${ }^{16-20}$ EDLFs include ouabain, digoxin, marinobufagenin (MBG), marinobufotoxin (MBT), telocinobufagin, proscillaridin A, bufalin and others. There are two types of EDLFs: cardenolides derived from plants and bufadienolides derived from toads. As these molecules contain a steroid nucleus and increase cardiac and vascular contractility by inhibiting $\mathrm{Na}^{+}, \mathrm{K}^{+}$-ATPases in cell membranes, they are called 'cardiotonic steroids' (CTSs).

Pharmacological evidence indicates that the circulating level of CTSs may not be high enough to exert physiological effects ${ }^{21,22}$ because the main $\mathrm{Na}^{+}, \mathrm{K}^{+}$-ATPase subunit, the $\alpha_{1}$-subunit, is resistant to ouabain. This apparent resistance was a major reason why CTSs were not researched extensively in terms of possible pathophysiological roles in cardiovascular disease. However, in recent years, EDLF has emerged as a key player, at least locally in the brain, in the onset of sodium-induced hypertension. ${ }^{23-25}$

${ }^{1}$ Department of Clinical Sciences and Laboratory Medicine, Kansai Medical University, Osaka, Japan and ${ }^{2}$ Cardiovascular Division, Toujinkai Hospital, Kyoto, Japan Correspondence: Professor H Takahashi, Department of Clinical Sciences and Laboratory Medicine, Kansai Medical University, Shinmachi 2-3-1, Hirakata City, Osaka 573-1191, Japan. 
In terms of blood pressure regulation, both a central nervous system (CNS) EDLF and the renin-angiotensin-aldosterone system (RAAS) in the CNS are important. ${ }^{26,27}$ Current antihypertensive agents may act at the sites responsible for blood pressure control in the CNS to decrease sympathetic outflow. ${ }^{28}$ Regardless of whether the CNS is involved in the genesis of hypertension in an individual patient, it is a major determinant of the response to antihypertensive therapy once a treatment strategy is adopted as commented by Esler. ${ }^{29}$ Sympathetic and parasympathetic nervous system activity and/or vasopressin release are the major mechanisms by which the CNS influences blood pressure, although other minor mechanisms may also be involved. When vasodilators are used, for example, the reactive increase in plasma catecholamine helps limit the decrease in blood pressure. Sympathetic activation may lead to a reactive increase in plasma renin activity (PRA) and to sodium retention, which also has an important role in limiting antihypertensive activity. Thus, the CNS is constantly regulating blood pressure toward its set point, and blood pressure is neither increased nor decreased unless the blood pressure set point is changed by the CNS. Among antihypertensive agents, the effectiveness of calcium channel blockers (CCBs) and RAAS inhibitors could reflect their specific actions in the CNS, which help reduce reactive vasopressor responses. In other words, current antihypertensive agents must act by affecting central hypertensive mechanisms and thus suppressing sympathetic outflow. Treatment strategies that address the implications of the CNS response are more likely to be effective than approaches that avoid or ignore CNS involvement.

This review presents recent advances in our understanding of the central mechanism of hypertension, including EDLF research. We also discuss the implications of this central mechanism of action in terms of the clinical treatment of hypertension.

\section{SODIUM AND HYPERTENSION}

Historically, humans in the Stone Age who lived inland on continents consumed minimal amounts of sodium salt in their diets. Until recently, Yanomamo Indians in the Brazilian Amazon region lived like Stone Age people, and their 24-h urinary excretion of sodium was $0.9 \mathrm{mmol}(0.53 \mathrm{~g}$ of $\mathrm{NaCl}) .{ }^{30}$ Notably, the amount of sodium they consumed was roughly one-twentieth of that consumed by people living in developed countries, ${ }^{31}$ suggesting that many humans today consume about 20 times more sodium salt than the minimum requirement. The average blood pressure of the Yanomamo Indians was $96.0 / 60.6 \mathrm{~mm} \mathrm{Hg}$ and did not increase with ageing. ${ }^{32}$ In addition, no hypertension was observed in this community, in contrast to other modern communities. In the Stone Age, the average life span was approximately 30 years. During this time, traits that worked to increase blood pressure with increasing stress would be favorable for survival: people who could easily elevate their blood pressure to provide sufficient blood to skeletal muscles and major organs would have a survival advantage when attacked by enemies or wild animals. Atherosclerosis, which is the greatest public health concern in modern society, would have no impact on Stone Age society, as there were few, if any, elderly people. Thus, the ability to easily increase blood pressure is a trait that might have conferred a survival advantage until modern times (Figure 1).

Sodium is the most essential mineral in mammalian physiology. In particular, ingestion of high amounts of sodium salt may be required to keep blood pressure high. As sodium intake is limited in natural foods, a physiological mechanism to prevent sodium loss into urine would have been established early in human evolution. The most powerful mechanism is the RAAS, ${ }^{33-35}$ which is maximally activated

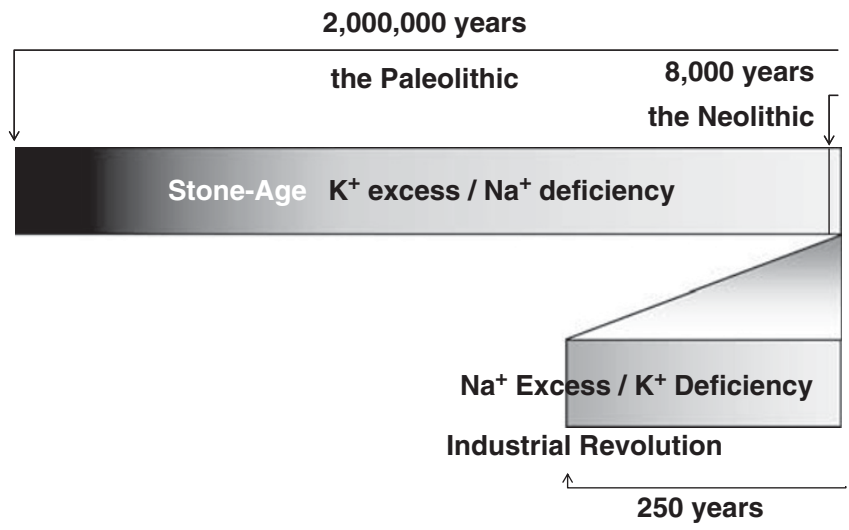

Figure 1 Humans have lived with a minimal intake of sodium for several million years. Accordingly, they have developed highly regulated physiological system mechanisms to retain sodium and maintain blood pressure at an appropriate level. The diet of humans has changed drastically and rapidly in recent years, with increased consumption of processed foods with high levels of sodium. Excessive dietary sodium may have adverse effects that lead to elevated blood pressure. A full color version of this figure is available at the Hypertension Research journal online.

in people with a minimal sodium intake. In addition, sodium is reabsorbed via the activated sympathetic nervous system, and reabsorption is specifically controlled by renal nerves. ${ }^{36-38}$ Insulin, which increases in metabolic syndrome (obesity) and in the initial stages of type 2 diabetes, also acts to retain sodium by suppressing sodium loss into urine via renal tubules. ${ }^{39-41}$ Obese people who are metabolically resistant to insulin are not resistant to renal tubular reabsorption of sodium by insulin. ${ }^{42}$ Although prevention of sodium loss may once have conferred a selective advantage, ingestion of excessive amounts of sodium now results in chronic hypertension, a major cause of atherosclerosis in modern society. Current efforts focus on preventing hypertension, and this historical perspective indicates that life style modification, and especially a diet that includes a minimum level of sodium salt, is very important for treating hypertension in the clinical setting. ${ }^{43,44}$

In contrast to sodium, potassium was abundant in the fresh foods that made up the Stone Age diet. There are few physiological mechanisms that control potassium retention, and potassium loss in urine is dependent on urine volume ${ }^{45-47}$ In modern times, diets have shifted drastically from fresh to processed foods, reducing potassium intake. ${ }^{48}$ As potassium supplementation leads to natriuresis, ${ }^{49}$ potassium deficiency may aggravate sodium overloading. Results of the Dietary Approaches to Stop Hypertension trial ${ }^{50}$ showed clearly that changes in diet, including both sodium restriction and potassium supplementation, are important for lowering of blood pressure. ${ }^{51}$

Epidemiological studies worldwide suggest that the optimal daily intake of sodium salt $(\mathrm{NaCl})$ is $6-7 \mathrm{~g},{ }^{52}$ roughly half of the current average intake of salt. However, because humans have lived with sodium deficiency for a long time, we have developed a powerful salt appetite. ${ }^{53}$ This innate desire for salty foods makes it very hard to drastically reduce sodium intake. In fact, when sodium salt is reduced in foods, older people in particular lose their appetites. Ideally, therapy to control hypertension would control pressor mechanisms induced by excess sodium intake even when a significant amount of sodium was consumed. Thus, 'hypertension and sodium' has been a major target of hypertension research for a long time, ${ }^{54-56}$ and there is increasing attention on endogenous digitalis as a key player in the hypertension-salt relationship. 
THE ROLE OF ENDOGENOUS DIGITALIS IN HYPERTENSION Is third factor endogenous digitalis?

Continuous administration of mineralocorticoids leads to sodium retention, which in turn leads to natriuresis when the sodium level exceeds a threshold. ${ }^{57,58}$ This phenomenon is known as 'mineralocorticoid escape.' The two major causes of natriuresis are increased glomerular filtration rate and decreased aldosterone levels, but neither is involved in mineralocorticoid escape. The factor involved in this phenomenon is thus referred to as 'the third factor', ${ }^{59}$ and the most likely candidate for this third factor is an EDLF: suppression of renal tubular $\mathrm{Na}^{+}, \mathrm{K}^{+}$-ATPase activity markedly increases sodium excretion, ${ }^{60,61}$ and EDLFs suppress this enzyme. Supporting this, a $\mathrm{Na}^{+}, \mathrm{K}^{+}$-ATPase inhibitor is increased in the circulation and tissue $\mathrm{Na}^{+}, \mathrm{K}^{+}$-ATPase activity is suppressed when animals are fed high-sodium diets. ${ }^{10,11}$ An extensive search for the third factor began a few decades ago. Of note, pigs treated with subcutaneous administration of deoxycorticosterone acetate plus $1 \%$ sodium chloride as drinking water develop antinatriuresis in the initial 2 days; at this point, digitalis-like $\mathrm{Na}^{+}, \mathrm{K}^{+}$-ATPase inhibitory activity increases at least 30 -fold compared with baseline and natriuresis occurs (Figure 2). ${ }^{62}$

\section{Endogenous digoxin was first explored as an EDLF}

Digoxin is used clinically as a CTS to treat arrhythmia and cardiac failure. ${ }^{63}$ As administration of excessive doses of digoxin leads to serious arrhythmias, the circulating levels of immunoreactive digoxin are monitored during digoxin therapy. Even when digoxin has not been given to patients, digoxin-like immunoreactivity (DLI) is sometimes detected in the plasma, ${ }^{64,65}$ possibly due to an EDLF that crossreacts with the anti-digoxin antibody. In fact, DLI is higher in deoxycorticosterone acetate-salt hypertensive rats than in control rats, ${ }^{66}$ and circulating DLI increases with sodium loading in rats. ${ }^{67}$ In humans, urinary DLI correlates with blood pressure and with urinary sodium. ${ }^{68}$ In 2000, our group identified circulating DLI as digoxin using liquid chromatography and mass spectrometry. ${ }^{69}$

\section{Ouabain is another candidate for an EDLF}

A hydrophilic digitalis, ouabain, has also been considered a potential EDLF. ${ }^{70-72}$ Hamlyn et al. ${ }^{73}$ isolated ouabain or its isomer from a very large volume of human serum in 1991. Our group used liquid chromatography and mass spectrometry ${ }^{69}$ and nuclear magnetic resonance $^{74}$ to demonstrate that there is ouabain in circulating human blood and in the culture supernatant of PC- 12 cells. Although there are very low concentrations of digoxin and ouabain in circulating blood in rodents and humans, ${ }^{75}$ their physiological roles are unclear because the $\mathrm{Na}^{+}, \mathrm{K}^{+}$-ATPase in rodents is resistant to these digitalis glycosides. ${ }^{76}$ However, a low dose of ouabain induces hypertension in rats, ${ }^{77}$ probably because suppression of $\mathrm{Na}^{+}, \mathrm{K}^{+}$-ATPase activity increases contraction of vascular smooth muscle and myocardium more or less. The $\alpha_{2}$-isoform is thought to be targeted by ouabain. ${ }^{78}$ Another explanation is that a low concentration of ouabain increases renal tubular $\mathrm{Na}^{+}, \mathrm{K}^{+}$-ATPase activity to augment sodium reabsorption, similar to aldosterone. ${ }^{79}$ This is not in accordance with the working hypothesis that endogenous digitalis is released and causes natriuresis to restore the sodium balance in response to excessive sodium accumulation. ${ }^{80}$ Molecules considered to act as EDLFs show exclusively hypertensive effects, ${ }^{81,82}$ but the underlying mechanisms of action seems complex. For example, nanomolar levels of ouabain increase the synthesis and release of angiotensin II (Ang II) from the endothelium of the tail vascular beds of spontaneously hypertensive rats, ${ }^{83}$ but also increase nitric oxide release from

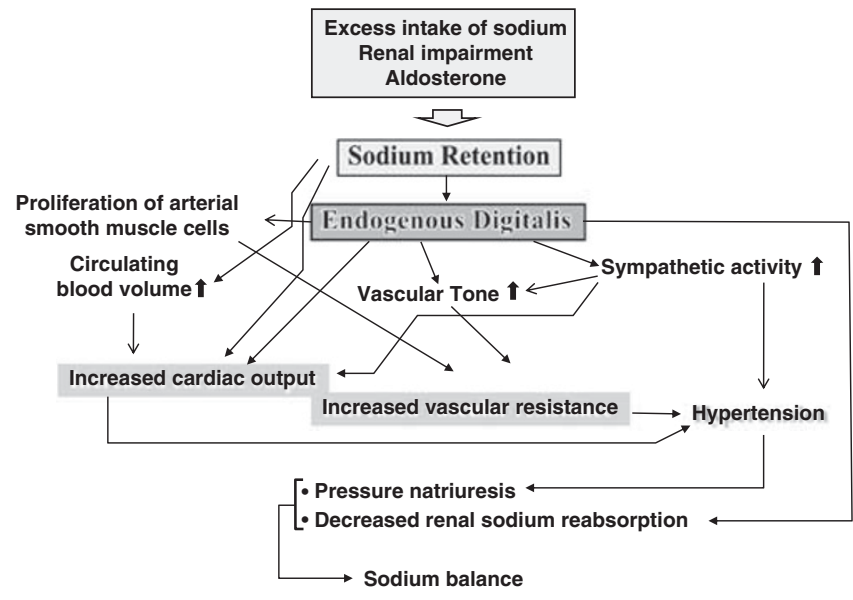

Figure 2 A working hypothesis for the development of hypertension associated with excess accumulation of sodium salt. Sodium retention stimulates production of endogenous digitalis, which elevates vascular tone and cardiac output. This increases blood pressure and directly inhibits the renal tubular $\mathrm{Na}^{+}, \mathrm{K}^{+}$-ATPase, resulting in reduced sodium reabsorption. Sodium balance is then achieved concurrently with the development of hypertension. A full color version of this figure is available at the Hypertension Research journal online.

endothelial cells. ${ }^{84}$ Ang II and nitric oxide have opposing effect on vascular smooth muscle as known well.

\section{The Milan hypertensive rat strain is the ideal animal model} for endogenous ouabain-induced hypertension

The Milan hypertensive rat has a point mutation in a gene that encodes adducin, ${ }^{85}$ which leads to the stimulation of $\mathrm{Na}^{+}, \mathrm{K}^{+}$-ATPase activity. As a result, renal tubular reabsorption of sodium increases, and sodium retention results in hypertension. ${ }^{86}$ In this animal model, plasma levels of ouabain-like immunoreactivity (OLI) are elevated, ${ }^{87}$ which is the principal cause of hypertension. PST2238 is an analogue of digitoxin to block the action of ouabain, which lowers blood pressure in the Milan hypertensive rats. ${ }^{88}$ PST2238 also suppresses hypertension caused by low-dose ouabain. ${ }^{89}$ Therefore, the cause of this type of hypertension is believed to be ouabain. It is thought that those having adducing polymorphism like similar to the one in Milan hypertensive rats, ${ }^{90,91}$ and PST2238 has potential for treating these patients. ${ }^{92}$ However, a recent large-scale clinical trial failed to find a significant reduction of blood pressure with PST2238. ${ }^{93}$

\section{Sites of production of endogenous digitalis: the hypothalamus and/or the adrenal gland?}

Digoxin and ouabain are of plant origin. As humans eat plants, we may be ingesting these substances. In fact, when isotope-labelled digoxin is fed to animals, it accumulates in the adrenal glands, brain and pituitary gland, which may be where digitalis is produced. ${ }^{94,95}$ For a long time, the question of whether digitalis detected in those organs and in plasma was of endogenous or exogenous origin was debated. ${ }^{55,96}$ However, it is now known that ouabain is absorbed poorly $(3-5 \%)$ in the intestine, indicating that it may be endogenous. $^{97}$

There is an interesting case report of an ouabain-producing adrenocortical tumor. ${ }^{98}$ The patient's hypertension returned to normal with extirpation of the tumor. We found that the plasma level of OLI was elevated in a patient with pheochromocytoma originated from the adrenal medulla. The level of OLI also decreased in this patient after extirpation of the tumor. ${ }^{99}$ 
When we investigated the tissue localization of OLI using a specific anti-ouabain antibody, OLI was detected in the adrenal medulla, ${ }^{100}$ paraventricular nucleus (PVN) and supraoptic nucleus in the hypothalamus, as well as in the pituitary gland. ${ }^{101,102}$ OLI-positive neurons were in the magnocellular region of the PVN. Their nerve fibers and varicosities also contain OLI, indicating that, similar to vasopressin, OLI is secreted from those neurons. The nerve fibers were distributed densely to the subfornical organ, organum vasculosum of the laminae terminalis and median eminence, which are implicated in water-electrolyte metabolism. ${ }^{103}$ OLI was also found at the posterior lobe of the pituitary gland. The exact same immunoreactivity pattern was found using an anti-digoxin antibody. ${ }^{104}$

The plasma levels of DLI increase and the hypothalamus levels decrease with sodium loading in rats. ${ }^{67}$ In contrast, when microtubules are destroyed with intracerebroventricular (ICV) injections of colchicine, the hypothalamic DLI content increases while the plasma levels decrease. ${ }^{67}$ We therefore thought that the turnover rate of DLI in the hypothalamus increased with sodium loading, suggesting that DLI was produced in the hypothalamus and possibly released from the pituitary. ICV treatments with 6-hydroxydopamine elicit decreases in OLI contents in the pituitary, the hypothalamus and the plasma. ${ }^{105}$ These results suggest that the production and release of OLI are closely associated with the brain, particularly the hypothalamus-pituitary axis, and that noradrenergic or dopaminergic neurons, or both, have a key role in this mechanism. Although we did not examine the turnover rate of OLI, it might be similar to that of DLI because OLI was observed in the same region of the hypothalamus.

Cultured immortalized cell lines have been used to study the mechanisms underlying the production of endogenous digitalis. When bovine adrenocortical cells are cultured in medium without serum, the level of OLI released in the medium is 10-fold higher than the OLI content in the cells. ${ }^{106}$ Y-1 cells of adrenocortical origin produce ouabain in culture too. ${ }^{107}$

$\mathrm{N} 1$ cells, which are an immortalized cell line of hypothalamic origin, were determined to be of PVN or supraoptic nucleus origin because they produce vasopressin and oxytocin. ${ }^{108}$ We recently found that ouabain is released into the serum-free culture medium of $\mathrm{N} 1$ cells in a time-dependent manner. ${ }^{109}$ Therefore, the hypothalamus as well as the adrenal gland produces ouabain.

Milan hypertensive rats show a roughly 10 -fold increase in ouabain content in their brains compared with control rats. ${ }^{87}$ The hypothalamus, but not the adrenal gland, of this animal model shows marked upregulation of genes coding for the P450 side chain cleavage enzyme and for the delta5-3beta-hydroxysteroid dehydrogenase/delta5-delta4isomerase enzymes. ${ }^{110}$ Knockdown of the gene coding for these enzymes decreases production of ouabain-like factor from neural tissue. ${ }^{110}$ Therefore, ouabain may be produced in the rat hypothalamus. We also found that rat PC-12 cells, which are of adrenomedullary origin, produce ouabain. ${ }^{73}$ As the adrenal medulla is of neural crest origin, this may suggest that neural tissues produce ouabain ubiquitously. As noted, OLI is also detected in the rat adrenal medulla by immunohistochemistry. ${ }^{99}$ To summarize, ouabain and digoxin are produced by neuronal cells in the hypothalamus and by adrenocortical and -medullary cells.

\section{Bufadienolides are acting as endogenous digitalis}

Bufadienolides are molecules with a six-membered lactone ring in the $\mathrm{C} 17$ position of the steroid nucleus (there is a five-membered lactone ring in this position in cardenolides of plant origin). Bufadienolides can be isolated from cataractous eye lenses ${ }^{111}$ and from toad skin and salivary glands. ${ }^{112}$ They have been used in traditional Chinese medicine. ${ }^{113}$ Similar to cardenolides, bufadienolides inhibit $\mathrm{Na}^{+}, \mathrm{K}^{+}-$ ATPase activity ${ }^{114,115}$ and are considered to be EDLFs and CTSs. Bufadienolides include MBG, MBT, telocinobufagin, telocinobufotoxin, bufalin, 19-norbufalin, proscillaridin A and others. Bufalin has positive inotropic and pressor responses associated with robust natriuretic activity, which are stronger than equimolar concentrations of ouabain. ${ }^{116}$ Of the bufadienolides, MBG has been studied most extensively. ${ }^{117-120}$ MBG has great affinity for and inhibits the activity of the $\alpha_{1}$-subunit of the $\mathrm{Na}^{+}, \mathrm{K}^{+}$-ATPase, ${ }^{80}$ which is the main $\mathrm{Na}^{+}$ pump isoform in vascular sarcolemma and renal tubules.

We originally isolated MBT, ${ }^{20}$ telocinobufagin ${ }^{121}$ and telocinobufotoxin $^{122}$ from human plasma and from cultured Y-1 and PC-12 cells. Some reports indicate that these bufadienolides are of adrenocortical origin. ${ }^{123,124}$ However, because the CNS has been implicated in electrolyte balance and blood pressure regulation, bufadienolides may also be produced in the nervous system. As the adrenal medulla is of neural crest origin, we investigated whether PC-12 cells produce these bufadienolides. Like ouabain, MBT, telocinobufagin and telocinobufotoxin were all found in cultured PC-12 cells. ${ }^{122}$ However, using the anti-MBG antibody, which cross-reacts with MBT, to perform immunohistochemical staining of the hypothalamus, we were unable to detect significant immunoreactivity in the hypothalamic nuclei. This may be due to technical reasons, because bufadienolides are lipophilic and may have been extracted into the organic solvent during sample tissue fixation.

In summary, bufadienolides seem to be produced mainly in the adrenal cortex. This contrasts with ouabain, which is produced mainly in the hypothalamus. These substances may work separately to regulate electrolyte balance and cardiovascular functions.

\section{Stimulation of CTS secretion}

On sodium loading, ouabain and digoxin levels increase not only in plasma but also in urine, ${ }^{10,117,125-128}$ suggesting that sodium loading triggers their production. Furthermore, OLI levels increase during exercise $^{129}$ and are elevated in patients with acute myocardial infarction. ${ }^{130,131}$ Thus, the role of these CTSs might be different from that of other CTSs that increase with sodium loading, particularly in the CNS.

In terms of long-term regulation of CTS secretion, OLI is increased in patients with chronic renal failure, ${ }^{121,132}$ primary aldosteronism, ${ }^{133,134}$ congestive heart failure ${ }^{135,136}$ and pre-eclampsia, ${ }^{137,138}$ and, to a lesser extent, in most patients with essential hypertension. ${ }^{132,139-142}$ Patients with essential hypertension have cardiac hypertrophy, bradycardia and increased ejection fraction, which are known pharmacological effects of digitalis glycosides. ${ }^{143}$ Plasma OLI concentrations decreased in obese subjects after 3 months of supervised exercise. ${ }^{144}$ As regular exercise decreases sympathetic activity and blood pressure, OLI may be involved in this mechanism.

Although plasma levels of OLI and DLI can increase or decrease in response to physiological and pathophysiological environmental factors, the magnitude of the changes is so small that it is hard to imagine that they have vasoconstrictive or cardiotonic effects in vivo. On the other hand, subtle local changes in levels in the brain may have significant biological effects, similar to those of a neurotransmitter or neuromodulator. Supporting this idea, microinjection of ouabain into the hypothalamus or lateral ventricle elevates blood pressure by increasing peripheral sympathetic activity. ${ }^{145-148}$ Therefore, plasma concentrations of these CTSs may originate in CNS tissue.

Thus, investigation of EDLFs led to the discovery of many other factors that act in concert with EDLF in response to sodium loading in the CNS. The proposed theory that sodium metabolism is influenced 
by EDLFs and other factors in the CNS, and that this is essential in the genesis of hypertension has now been confirmed.

\section{ACTIVATION OF THE BRAIN RAAS BY SODIUM LOADING}

Antihypertensive agents such as CCBs, angiotensin I-converting enzyme inhibitor (ACEI), angiotensin type-1 receptor blocker (ARB) and mineralocorticoid receptor blocker (MRB) are very useful in controlling hypertension of any cause in the clinical setting. ${ }^{149-153}$ RAAS blockers in particular may be superior to other agents because they can prevent the onset of diabetes mellitus ${ }^{154,155}$ and protect against cardiovascular complications. ${ }^{156-159}$ ACEI completely restores normal blood pressure levels in rats with spontaneous hypertension. ${ }^{160,161}$

Sodium loading suppresses PRA and serum aldosterone concentration. ${ }^{162}$ Therefore, the RAAS was not thought to be essential in the pathogenesis of hypertension on sodium loading. In patients with essential hypertension who may have high-sodium consumption, roughly one-third have lower PRA. ${ }^{163,164}$ RAAS blockers were still effective in these patients. ${ }^{165,166}$ Unexpectedly, MRB is more effective in patients with low-renin essential hypertension than in high-renin patients. ${ }^{167}$

PRA mainly reflects the activity of renal renin, but there is renin not only in salivary glands ${ }^{168}$ but also in the brain. ${ }^{169}$ Expression of renal renin mRNA markedly increases with sodium depletion and captopril treatment, whereas brain renin mRNA decreases. ${ }^{170}$ Brain renin may differ from that produced elsewhere as the end product, Ang II in the CNS, causes sympathetic activation and increases blood pressure. ${ }^{171-175}$ When we examined renin mRNA in the hypothalamus, expression was higher in rats fed a high-salt diet compared with control rats with a normal diet. ${ }^{176}$ Similarly, expression of ACE mRNA and angiotensin type- 1 receptor mRNA was higher in deoxycorticosterone acetate-salt hypertensive rats, ${ }^{177}$ and ICV injection of Ang II causes far greater rises in blood pressure in those rats than in control rats. So, in contrast to its effect on PRA, sodium loading increases the activity of the brain renin-angiotensin system. There is aldosterone in the hypothalamus, ${ }^{178}$ and its levels increase with sodium loading in rats, ${ }^{179}$ suggesting that sodium loading activates the brain RAAS. Both Ang II and aldosterone injected ICV cause centrally induced increases in blood pressure. ${ }^{180,181}$ Therefore, activation of the brain RAAS may be an essential cause of hypertension. If RAAS blockers affect central sites, it makes sense that they are effective even in low-renin essential hypertensives. ${ }^{164,165}$

In our experience, the hypertensive response to ICV injection of hypertonic saline is accompanied by an increase in the plasma DLI concentration, which is blocked by ICV pretreatment with ARB. ${ }^{182}$ On the basis of this, we proposed that sodium loading could activate the brain renin-angiotensin system, with EDLFs implicated in this series of responses. Blood pressure increases after ICV injection of hypertonic saline are accompanied by increased peripheral sympathetic tone. ${ }^{183,184}$ In particular, renal nerve activity markedly increases with ICV injection of hypertonic saline, ${ }^{185}$ and renal arterial blood flow, as measured with radioactive microspheres, decreases. ${ }^{186}$ As this response is reversed by ICV pretreatment with atrial natriuretic peptide or C-type natriuretic peptide, it appears that these peptides compete with the RAAS in the brain. There are natriuretic peptides in the brain, ${ }^{187,188}$ and brain natriuretic peptide and C-type natriuretic peptide were originally isolated from the brain. Elevated sympathetic activity acts as a powerful anti-natriuretic factor. ${ }^{189}$ Therefore, sodium loading may lead to sodium retention via the central mechanism (that is, positive feedback). However, lower concentrations of ICV sodium suppress renal sympathetic nerves ${ }^{190}$ and cause natriuresis in rats ${ }^{191}$ and sheep ${ }^{192}$ (that is, negative feedback). It is hard to understand which mechanism is actually working in vivo. There may be a sodium level threshold in the cerebrospinal fluid that triggers the positive feedback mechanism.

\section{IS THE EPITHELIAL SODIUM CHANNEL (ENAC) A SENSOR FOR SODIUM IONS IN THE BRAIN?}

Vasopressor responses to ICV injections of hypertonic saline may not be triggered by nonspecific stimuli like osmotic pressure, because equimolar amounts of urea injected ICV do not cause the same response. ${ }^{193}$ As we taste sodium salt via $\mathrm{ENaCs}$ on our tongues, ${ }^{194,195}$ we proposed that $\mathrm{ENaC}$ also works as a sensor for sodium ions in the CNS. The increases in blood pressure and sympathetic hyperactivity caused by ICV injection of hypertonic saline are abolished with ICV pretreatment with benzamil, a selective $\mathrm{ENaC}$ blocker. ${ }^{196}$ Wang et al. ${ }^{197}$ studied the relationship between $\mathrm{ENaC}$ and ouabain in the CNS and found that ICV injection of low-dose aldosterone in artificial cerebrospinal fluid with elevated sodium content markedly elevated blood pressure and sympathetic activity; these effects were abolished by ICV pretreatment with benzamil. Furthermore, ICV pretreatment with digibind, the $\mathrm{Fc}$ fragment of the anti-digoxin antibody that blocks ouabain's inhibition of the $\mathrm{Na}^{+}, \mathrm{K}^{+}$-ATPase, also significantly suppressed the hypertensive activity of aldosterone and hypertonic artificial cerebrospinal fluid. This group conducted a series of studies of these relationships, ${ }^{198-202}$ and others reported similar findings. ${ }^{203}$

Taken together, these findings indicate that $\mathrm{ENaC}$ may sense $\mathrm{Na}^{+}$in CSF and stimulate aldosterone production. This triggers the release of ouabain, which in turn activates sympathetic outflow and causes hypertension.

\section{THE RELATIONSHIP BETWEEN THE RAAS AND OUABAIN IN THE BRAIN}

As noted, pressor responses and increases in plasma DLI after ICV injections of hypertonic saline are abolished by ICV pretreatment with ARB. ${ }^{182}$ The renin-angiotensin system is upregulated in rats fed a high-salt diet, as shown by increased expression of renin, ${ }^{176}$ and ACE and angiotensin type- 1 receptor mRNA. ${ }^{177}$ ICV injection of Ang II causes greater pressor responses in rats fed a high-salt diet than in rats with normal sodium levels. Augmented central pressor responses to Ang II in sodium-loaded rats are supported by the work of Houghton et $a .^{26}$ Increased production of Ang II in the hypothalamus in response to sodium loading has been shown using microdialysis, ${ }^{204}$ and there is sodium retention in rats with renal failure, indicating that the brain renin-angiotensin system is upregulated. ${ }^{205}$ Pressor responses to ICV infusion of high-sodium artificial cerebrospinal fluid are blocked by ICV pretreatment with spironolactone, an MRB. ${ }^{197}$ Thereby, hypothalamic aldosterone is increased and OLI content is decreased in both the hypothalamus and pituitary gland by spironolactone. This indicates that the higher levels of sodium ion in the artificial cerebrospinal fluid stimulated production of aldosterone and ouabain. The enzymes required for aldosterone synthesis from cholesterol are expressed in the brains of both rats ${ }^{206,207}$ and humans, ${ }^{208}$ and there are minoralocorticoid receptors (MRs) in the brain. ${ }^{207}$ Dahl salt-sensitive rats have higher hypothalamic aldosterone levels than in Sprague-Dawley rats. ${ }^{209}$ These findings suggest that increased sodium ion levels trigger activation of the RAAS, releasing ouabain and leading to sympathetic activation as indicated by Huang et al. ${ }^{210}$ However, ICV treatment with aldosterone elevates reninangiotensin system activity in the brain. ${ }^{211}$ Therefore, there are complex interactions involving renin, angiotensin, aldosterone and ouabain in the brain. Ouabain acts downstream of aldosterone in this scenario, because spironolactone blocks the sodium ion-dependent increase in brain OLI. ${ }^{197}$ 
To summarize, the RAAS in the brain is activated by sodium ions, which causes pressor responses via activation of the sympathetic nervous system.

\section{CENTRAL ACTIONS OF ANG II AND ALDOSTERONE OF PERIPHERAL ORIGIN}

It has been known for at least 40 years that Ang II injected into vertebral arteries causes pressor responses and sympathetic activation. ${ }^{27,212}$ ICV injection of Ang II also elicits pressor responses along with sympathetic overactivity. ${ }^{171-175}$ These findings show that Ang II of peripheral or central origin directly affects the central vasomotor center to cause sympathetic activation. In fact, peripheral administration of Ang II causes sympathetic activation irrespective of the pressor response. ${ }^{213,214}$ However, generally speaking, pressor responses to subcutaneous or intravenous injections of Ang II were long thought to be due to Ang II's direct vasoconstrictive activity and inotropic actions on the heart because Ang II is a very potent vasoconstrictor in vivo. The finding in 2010 that pressor responses to systemic administration of Ang II are mediated exclusively via the CNS was thus surprising. ${ }^{215}$ In that study, ICV pretreatment with an aldosterone synthase inhibitor abolished pressor responses to subcutaneous infusion of low-dose Ang II. When the dose of Ang II was high, the pressor response was only partially inhibited because the direct peripheral effects overcame the central effects. Moreover, the inhibitory effects could be reproduced by ICV pretreatment with either eplerenone or digibind. ${ }^{215}$ Another research group reported similar findings: ICV infusion of an MRB, RU28318, almost completely blocked the pressor responses to subcutaneous infusions of Ang II. ${ }^{216}$ Furthermore, chronic intravenous infusion of Ang II gradually increased blood pressure, reaching a plateau level after about 2 weeks. ${ }^{217}$ Fra-like activity, an indicator of chronic neuronal activation, was increased in the PVN in that study. ICV treatment with losartan (an ARB), tempol (a reactive oxygen scavenger) or pyrrolidine dithiocarbamate (an NF- $\kappa \mathrm{B}$ inhibitor), all abolished hypertensive responses to intravenously infused Ang II.

These mechanisms of actions of Ang II are very different from its established roles in constricting arteries and increasing cardiac muscle contractility. However, these studies show that aldosterone production may be induced by Ang II via angiotensin type-1 receptors in the brain, once again suggesting that the brain RAAS is acting to regulate systemic circulation. We may have to change our concept of aldosterone's mechanism of action as well. Aldosterone acts on renal tubules, inducing sodium retention, and also exerts inotropic effects on the heart. $^{218-220}$ However, these effects may not underlie hypertension induced by aldosterone; instead, aldosterone's site of action may be the hypothalamus.

The finding that the pressor responses to Ang II are abolished by tempol and pyrrolidine dithiocarbamate indicates that Ang II leads to oxidative stress in the brain. ${ }^{217}$ Similar findings showing that oxidative stress in the brain is reduced by olmesartan, an ARB, have been reported in stroke-prone spontaneously hypertensive rats. ${ }^{221}$ Renal sympathetic discharge caused by ICV injection of Ang II is suppressed by ICV treatment with tempol, supporting the idea that Ang II elicits an oxidative stress reaction in the brain to cause hypertension. ${ }^{222}$ When aldosterone is infused subcutaneously in rats with supplementation of $1 \%$ saline as drinking water for 4 weeks, blood pressure gradually increases by about $30 \mathrm{~mm} \mathrm{Hg}$ with concomitant increases in (salty) water drinking. ${ }^{216}$ In that study, when irbesartan (an ARB), RU28318 or spironolactone were infused ICV with osmotic minipumps, the pressor responses caused by subcutaneous aldosterone plus salt loading were abolished in all three pretreatment groups, ${ }^{216}$ and the increase in saline intake was lower. As these pressor responses were inhibited by nicotinamide adenine dinucleotide phosphate inhibitors, that is, apocynin or tempol, aldosterone must be acting as an oxidative stressor. ${ }^{216}$ However, the drinking behavior was not blocked by apocynin or tempol, in contrast to the actions of ARB and MRB. Therefore, salt appetite and pressor mechanism may be regulated independently in the brain. Further, drinking salty water is not directly related to aldosterone's pressor activity, although it may affect the longterm control of blood pressure. These findings are supported by a report that showed that blood pressure increases accompanied by sympathetic activation were ameliorated by RU28318, losartan or tempol. ${ }^{211}$

Both RAAS and sympathetic nervous system activity are increased in patients with heart failure. Specifically, plasma and hypothalamic aldosterone levels are increased in a rat ischemia-induced heart failure model. ${ }^{223}$ Further, the rats with heart failure showed higher mRNA and protein expression levels of ACE and Ang II type$1 \mathrm{R}$, and expression was suppressed by ICV treatment with RU28318. ${ }^{223}$ RU28318 also suppressed the excitation of PVN neurons in the hypothalamus, and the plasma level of norepinephrine was lower. Thus, aldosterone of adrenocortical origin appears to reach the hypothalamus, triggering a series of events accompanied by the progression of heart failure. As systemic administration of aldosterone causes hypertension, which is abolished by a small dose of ICV-infused MRB, ${ }^{216}$ these observations show that aldosterone is actually acting at MRs in the CNS to cause sympathetic excitation and hypertension. The renin-angiotensin system may be downstream of the MR, because aldosterone elicits oxidative stress to activate the renin-angiotensin system (because MRB decreases nicotinamide adenine dinucleotide phosphate-mediated superoxide production in the hypothalamus). An excellent review article describing oxidative stress in the CNS and sympathetic activation is appeared recently. 224

These findings indicate that Ang II and aldosterone independently cause oxidative stress in the brain, increasing sympathetic activation and leading to increases in blood pressure. They further indicate that aldosterone upregulates the renin-angiotensin system. These novel findings regarding the central actions of Ang II and aldosterone are exciting for people working in the field of hypertension research.

\section{CENTRAL MECHANISMS OF HYPERTENSION}

The CNS regulates blood pressure, and the baroreceptor reflex mechanism acts as a homeostatic mechanism for stabilizing blood pressure. ${ }^{225}$ However, baroreceptors only stabilize blood pressure at the set point rather than actually determining the set point. ${ }^{226-228}$ Regulation occurs via the medulla oblongata, and the set point is thought to be determined by the higher center of the central vasomotor control, possibly in the hypothalamic nuclei, that is, the PVN and supraoptic nucleus. ${ }^{229}$ The baroreceptor set point in hypertensive individuals is shifted to a higher level, and their baroreceptor sensitivity is lowered. ${ }^{230}$ When ACEI is administered systemically to decrease circulating Ang II, the set point shifts to a normal level as does the baroreceptor sensitivity. ${ }^{230}$ Even when blood pressure is increased to hypertensive levels by phenylephrine infusion, the set point remains in the normal range. This indicates that Ang II is essential for determining the blood pressure set point. Consequently, blockade of the renin-angiotensin system restores blood pressure to normal. Although it seems logical that ACEI decreases Ang II in the peripheral circulation, it may act on the CNS. In either case, because the CNS is the control center for circulation, Ang II acts at the central site to shift the blood pressure set point. 
As the brain RAAS is activated when there is excessive intake of sodium salt, the effect is opposite that of ACEI administration: the blood pressure set point is raised, that is, hypertension develops. Needless to say, EDLF is important in the central mechanism of action of the sodium-RAAS cascade.

\section{CENTRAL EFFECTS OF OTHER STEROID HORMONES}

Although centrally induced vasopressor responses have been documented for aldosterone, ${ }^{209,210}$ the central effects of glucocorticoids and sex hormones are less well established. Our group showed that cortisol acts at a central site to increase sympathetic outflow and cause vasopressor responses that are abolished by ICV pretreatment with ACEI or [1-Sar, 8-Ileu] Ang II. ${ }^{231}$ Cortisol is converted to cortisone by $11 \beta$-hydroxy steroid dehydrogenase- 2 locally at the affected site. ${ }^{232}$ MRs have equal affinity for aldosterone and cortisol, ${ }^{233}$ but because cortisol is converted to cortisone by $11 \beta$-hydroxy steroid dehydrogenase-2 before acting at MRs, cortisol usually does not affect MRs. However, if $11 \beta$-hydroxy steroid dehydrogenase- 2 is absent in tissues where MRs are present, cortisol can bind to MRs and have the same effects as aldosterone. It is clear that MRs are expressed in the hypothalamus, ${ }^{234}$ but $11 \beta$-hydroxy steroid dehydrogenase- 2 is barely detectable there. ${ }^{235,236}$ Thus, when circulating cortisol reaches its sites of actions in the CNS, it may directly affect MRs, increasing sympathetic activity and hypertension when circulating cortisol reached at the site of actions in the CNS. If the response was caused by stimulation of MR by cortisol, renin-angiotensin system may be at the down-stream of mineralocorticoid. Although no one has tested, EDLF may also be involved in this cascade.

Conjugated estrogen also elicits centrally induced vasopressor responses, which can be abolished by blocking actions of AngII, ${ }^{237}$ which is very similar to the central action of cortisol and aldosterone.

Collectively, not only aldosterone but also glucocorticoids and sex hormones may be acting at the CNS to cause hypertension, corresponding to Cushing's syndrome and pregnancy-induced hypertension in a clinical setting, respectively.

\section{A HYPOTHESIS IN GENESIS OF HYPERTENSION}

When we considered these epidemiological and experimental facts mentioned earlier, a hypothesis may appear. The human who evolved in the salt-deficient environment, has strong salt appetite together with a powerful mechanism to retaining sodium. The RAAS and the sympathetic nervous system made it possible for humans to survive during the Stone Age, because higher blood pressure levels allowed humans to respond and fight enemies and wild animals by increasing the blood supply to the heart and skeletal muscles.

The renal RAAS developed so that changes in the sodium balance could be corrected quickly using negative feedback. In addition, another powerful positive feedback system, possibly the brain EDLF/RAAS, controls long-term maintenance of sodium retention and maintains elevated blood pressure. The sodium balance is thus controlled by opposing forces in the CNS and in the periphery.

Humans may have evolved to be prone to elevated blood pressure via excitation of sympathetic nerve activity in response to stimuli such as sodium loading. The switch in modern times to a diet that includes a lot of salty food has led to elevated blood pressure, which may cause essential hypertension. What, then, is the cause of secondary hypertension? In renovascular hypertension, activation of the RAAS in the CNS causes hypertension directly via Ang II and aldosterone. In patients with primary aldosteronism, increased aldosterone directly affects the CNS. Sodium retention because of hyperaldosteronism may

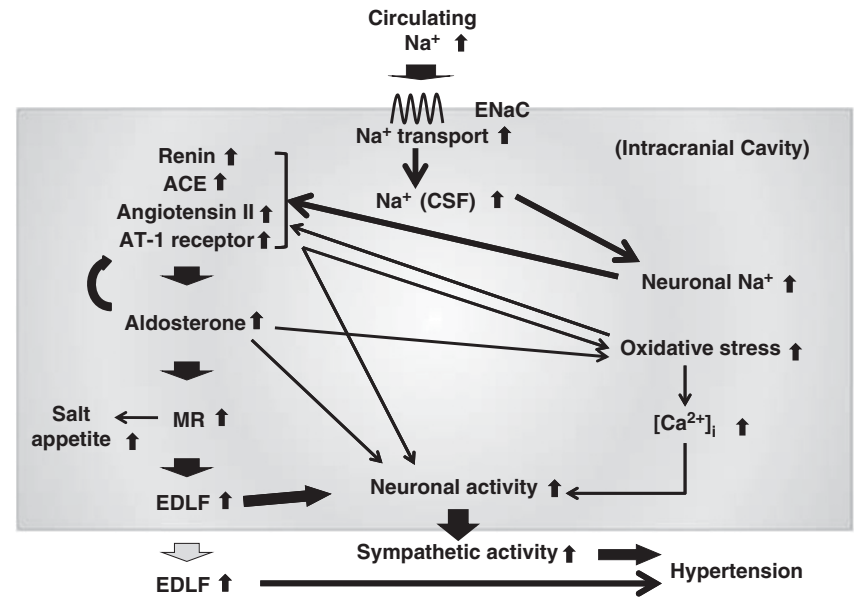

Figure 3 A proposed cascade showing sympathetic activation in the brain and the development of hypertension, which is triggered by elevated circulating sodium ion levels. Sodium ions are absorbed via epithelial sodium channels, further activating the brain renin-angiotensin-aldosterone system. Aldosterone stimulates the production of endogenous digitalis, possibly ouabain, in the paraventricular and supraoptic nuclei to trigger sympathetic activation. Angiotensin II and aldosterone cause oxidative stress, which also stimulates sympathetic outflow in the central nervous system. A full color version of this figure is available at the Hypertension Research journal online.

also contribute to centrally induced hypertension. Sodium retention because of impaired renal function may account for the response to sodium loading in patients with renal hypertension and in older hypertensive patients with impaired renal function.

In conclusion, CNS control of sodium metabolism underlies every type of hypertension, including essential hypertension, primary aldosteronism, pheochromocytoma, renovascular hypertension, renal hypertension and pregnancy-induced hypertension (Figure 3).

\section{ANTIHYPERTENSIVE AGENTS AND THE CENTRAL MECHANISM OF BLOOD PRESSURE REGULATION}

The key factors in the sodium-induced mechanisms of action of hypertension include $\mathrm{Na}^{+}, \mathrm{ENaC}$, the RAAS, EDLF, oxidative stress and the CNS sympathetic nervous system. Agents that influence these factors can either induce or decrease hypertension (Figure 4). Antihypertensive agents in particular must affect these factors; otherwise, treatment with antihypertensive agents would be accompanied by adverse circulatory events. That is, if the baroreceptor reflex set point is not lowered, the CNS will struggle to restore blood pressure to a higher level. For example, vasodilators such as hydralazine ${ }^{238}$ and short-acting dihyropyridine $\mathrm{CCBs}^{239}$ often cause angina pectoris by increasing sympathetic tone. In fact, although excellent antihypertensive agents are now available, many antihypertensive agents have been screened during the long clinical history of hypertension treatment, only to be rejected because of adverse events. ${ }^{240,241}$ A number of largescale clinical trials have evaluated the prognosis of current antihypertensive agents and provided evidence of their efficacy. ${ }^{242-245}$

Diuretics lower blood pressure by affecting the central mechanism of hypertension. Specifically, diuretics lower the concentration of circulating $\mathrm{Na}^{+}$, decreasing sympathetic outflow. However, decreased venous return to cardiopulmonary region because of circulating volume contraction decreases the low-pressure baroreceptor reflex tone (the sensors are located in the cardio-pulmonary region) and increases sympathetic activity. ${ }^{246}$ As a result, sympathetic activity 


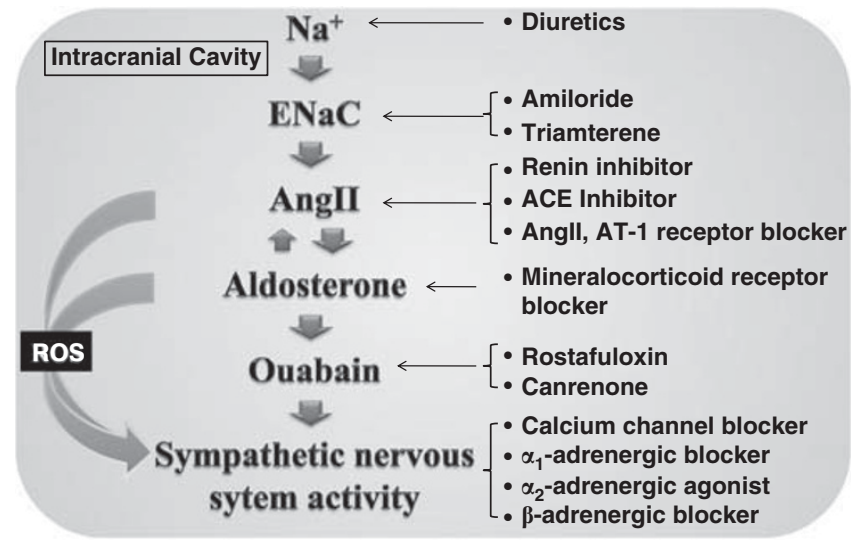

Figure 4 The cascade that causes sympathetic hyperactivity in the brain and the antihypertensive agents that target components in this cascade. Currently available antihypertensive agents appear to act at the level of the central nervous system to decrease sympathetic outflow. Therefore, reflex tachycardia is absent when blood pressure is lowered with these agents, that is, the baroreceptor set point is reset to a lower level in patients treated with these antihypertensive agents. A full color version of this figure is available at the Hypertension Research journal online.

increases after treatment with diuretics in a clinical setting, ${ }^{247}$ but blood pressure is decreased and sympathetic hyperactivity is minimal probably due to the central actions of decreased $\mathrm{Na}^{+}$concentrations. Thus, diuretics end up decreasing sympathetic activity and do not result in reflex tachycardia when blood pressure is significantly decreased. ${ }^{248}$

Local blockade of ENaCs in the CNS should reduce blood pressure in humans as well as in animal models. In fact, amiloride and triamterene, which are used to treat hypertension, ${ }^{249,250}$ are thought to act at the distal renal tubules to suppress $\mathrm{Na}^{+}$and $\mathrm{K}^{+}$exchange in the kidney and thereby lower blood pressure. It is also possible that these agents act directly on the central site.

Blockade of the RAAS with a direct renin inhibitor, ACEI, ARB or MRB is powerful treatment for almost all types of hypertension. ${ }^{251-254}$ These agents most likely act on the most essential part of the central mechanism of hypertension and are considered the best antihypertensive agents because of positive results from a number of large-scale clinical trials. $^{242-245,255}$ All are used worldwide. Systemic administration of ARB in rats prevents sympathetic hyperactivity and hypertension caused by ICV injection of hypertonic saline ${ }^{256}$ or Ang II. ${ }^{257}$ Possibly because these agents act on the central mechanism of hypertension, they have few adverse effects. The prognosis of hypertensive patients treated with these agents is also good as the agents prevent cardiovascular complications. ${ }^{258-262}$

Agents that block EDLF actions may be candidates for antihypertensive agents, with PST2238 (rostafuroxin) serving as a prototype drug. ${ }^{88}$ Although there were no significant hypotensive effects in a clinical trial in a general population, ${ }^{92}$ very effective hypotension was achieved via increased plasma ouabain levels in patients with genetic variants such as those in adducin 1 , lanosterol synthase, hydroxyl- $d-5$ steroid dehydrogenese and ATP-binding cassette sub-family B member $1 .^{90,263}$ Therefore, agents that selectively affect EDLF activity may be worth developing.

Sympatholytic agents such as $\alpha_{2}$-adrenergic agonists and imidazoline receptor agonists are also useful antihypertensive agents. ${ }^{264,265}$ Those are acting at the vasomotor center in the lower brain stem to decrease sympathetic outflow, which again suggest that sympathetic nervous system activity is a key factor for regulation of blood pressure.
However, adverse effects such as drowsiness and dry mouth limit the use of these agents, particularly $\alpha_{2}$-adrenergic agonists.

The $\alpha_{1}$-adrenoceptor blocker is thought to act on $\alpha_{1}$-receptors in the peripheral arterial wall to dilate vessels, which is the principal effect of this agent. ${ }^{266}$ If this blocker works purely as a vasodilator, reflex tachycardia will occur in response to hypotension and the antihypertensive actions will be limited. In fact, pulse rate does not increase in response to hypotension caused by prazosin, doxazosin and bunazosin. ${ }^{267}$ When injected intravenously in anesthetized rats, bunazosin lowers blood pressure by suppressing sympathetic outflow. ${ }^{268,269}$ Therefore, we assume that these $\alpha_{1}$-receptor blockers act directly at central $\alpha_{1}$-receptors to suppress sympathetic outflow. This may be why treatment with these agents does not result in reflex tachycardia.

CCBs are widely used because they are potent antihypertensive agents with minimal adverse effects. Again, this kind of agent does not induce reflex tachycardia regardless of its hypotensive effect, except when it acts rapidly. ${ }^{270,271}$ Some agents act directly on cardiac muscle to suppress pacemaker activity. ${ }^{272,273}$ Even with dihydropyridine CCBs, which have less of an effect on the pacemaker, reflex tachycardia is usually absent and the heart rate may decrease. ${ }^{271}$ Of course, reflex tachycardia occurs when a potent CCB like nifedipine is administered and rapidly lowers blood pressure. ${ }^{274}$ However, when blood pressure is lowered gradually with slow-release nifedipine or amlodipine, reflex tachycardia is absent; instead, there is bradycardia. ${ }^{275,276}$ Thereby, peripheral sympathetic tone is decreased. ${ }^{276}$ Therefore, when CCBs are administered, there are effects that are very similar to those induced by $\alpha_{1}$-blockers. Diltiazem given intravenously causes hypotension and bradycardia without peripheral sympathetic excitation. ${ }^{277}$ ICV injections of diltiazem elicit vasodepression with decreases in abdominal sympatholytic activity, which is attenuated by electric ablation of the hypothalamic anteroventral third ventricle area. ${ }^{277}$ Similar findings have been reported with nifedipine in rats on a high-salt diet. ${ }^{278}$

Beta-adrenergic blockers cause centrally induced vasodepression: ICV injections of propranolol, a representative $\beta$-blocker, elicits vasodepressor responses accompanied by suppression of sympathetic outflow. ${ }^{279,280}$ Intravenous injections of propranolol act on the brain to raise the local concentrations to levels similar to those observed after ICV injection to induce hypotension. ${ }^{281}$ Those will be the reason why $\beta$-blockers are widely used for treatment of patients with congestive heart failure, who have elevated peripheral sympathetic tone.

The blood-brain barrier blocks the entry of most substances into the brain. Therefore, except for centrally acting $\alpha_{2}$-adrenergic agonists, antihypertensive agents do not generally reach CNS sites. On the other hand, circumventricular organs such as the subfornical organ and the organum vasculosum of the laminae terminalis are critical centers for blood volume and blood pressure regulation. ${ }^{282-286}$ The arterial architecture differs in the organum vasculosum of the laminae terminalis and in the area postrema, so there are also differences in terms of the solutes that permeate them. ${ }^{287}$ These areas may serve as overall sensors for body fluid and circulatory regulation. The anteroventral third ventricle area, which includes the organum vasculosum of the laminae terminalis, has been implicated in the genesis of several types of experimental hypertension ${ }^{288-293}$ and may include a network of neurons that regulate electrolyte balance and sympathetic tone. Circumventricular organs have a less selective blood-brain barrier and may directly (chemically) sense the circulatory environment. When the subfornical organ is electrically ablated, pressor responses to chronic subcutaneous infusion of Ang II are attenuated ${ }^{27}$ and the 
antihypertensive effects of ARB are decreased. Thus, Ang II and ARB may act on the subfornical organ.

The common characteristic of the first and second choice of antihypertensive agents recommended by clinical guidelines ${ }^{294,295}$ is that they do not result in reflex tachycardia during hypotension. This means that a baroreflex system senses that the blood pressure level because of antihypertensive agents is the correct one for the patient. Current antihypertensive agents may reset the baroreceptor reflex threshold to a lower level, a process that must be controlled by the CNS rather than by peripheral barosensors. As noted, antihypertensive agents would have suppressed sympathetic nervous system activity in which level blood pressure converge to restore the sympathetic activity.

Thus, the ENaC-RAAS-EDLF system in the CNS may elicit sympathetic hyperactivity in the sodium-loaded state, leading to an elevation in the blood pressure set point. Sodium retention occurs not only because of excessive intake of sodium salt but also because of decreased excretion of sodium because of impaired renal function in renal hypertension, primary aldosteronism, insulin resistance and senile essential hypertension with renal impairment. Sodium retention is the common underlying cause of almost all types of hypertension. Therefore, treatments for hypertension, including diuretics, ACEI, $\mathrm{ARB}, \mathrm{MRB}, \alpha_{1}$-blocker, $\alpha_{2}$-agonist and $\beta$-blocker, all interfere with this cascade to break the chain that leads to hypertension.

The antihypertensive agents screened during the long history of antihypertensive therapy allow us to lower blood pressure comfortably and improve prognosis. This may indicate that these antihypertensive agents act at the origin of hypertension, that is, the CNS. Therefore, with this understanding of the genesis of hypertension, efforts should focus on novel antihypertensive agents that selectively target this cascade.

\section{FUTURE TASKS}

Despite the long history of hypertension research, some of the possible mechanisms of action of antihypertensive agents have been ignored. Although the brain controls the sympathetic nervous system (and thus hypertension), it seemed unlikely to researchers that antihypertensive therapies targeted the brain. This may be why it took so long to elucidate the pathogenesis of hypertension. We can now forget that such agents can change patients' personalities and may have other serious side effects. Physiological variables such as respiration and body temperature are controlled by the CNS, and the CNS is the overall regulator of many physiological functions, including blood pressure. ${ }^{29}$ Sympathetic activation represents a hallmark of the essential hypertensive state and its complications. ${ }^{296}$ Some issues remain to be clarified, including the following:

(1) Does ouabain, digoxin or another $\mathrm{Na}^{+}, \mathrm{K}^{+}$-ATPase inhibitor function as an EDLF in the CNS?

(2) The evidence establishing the connections in the Na-ENaCRAAS-EDLF network remains incomplete.

(3) The expression of genes associated with the Na-ENaC-RAASEDLF network must be determined.

(4) Most evidence supporting the central role of this network in blood pressure regulation was obtained in animal models or cultured cells. We must determine whether there is a similar series of responses in humans.

Despite these remaining questions, the paths that lead to hypertension are becoming clearer, and a full understanding of the mechanisms underlying hypertension may be close at hand.
1 Dahl LK, Love RA. Evidence for relationship between sodium (chloride) intake and human essential hypertension. AMA Arch Intern Med 1954; 94: 525-531.

2 Sasaki N. The relationship of salt intake to hypertension in the Japanese. Geriatrics 1964; 19: 735-744.

3 Swaye PS, Gifford Jr RW, Berrettoni JN. Dietary salt and essential hypertension. Am J Cardiol 1972; 29: 33-38.

4 Stamler J. The INTERSALT study: background, methods, findings, and implications. Am J Clin Nutr 1997; 65: 626S-642S.

5 Erdem Y, Arici M, Altun B, Turgan C, Sindel S, Erbay B, Derici U, Karatan O, Hasanoglu E, Caglar S. The relationship between hypertension and salt intake in Turkish population: SALTURK study. Blood Press 2010; 19: 313-318.

$6 \mathrm{Kim}$ HJ, Paik HY, Lee SY, Shim JE, Kim YS. Salt usage behaviors are related to urinary sodium excretion in normotensive Korean adults. Asia Pac J Clin Nutr 2007; 16: $122-128$.

7 Swales JD. Studies of salt intake in hypertension. What can epidemiology teach us? Am J Hypertens 1990; 3: 645-649.

8 Ohta Y, Tsuchihashi T, Onaka U, Miyata E. Long-term compliance of salt restriction and blood pressure control status in hypertensive outpatients. Clin Exp Hypertens 2010; 32: 234-238.

9 He FJ, Mac Gregor GA. Effect of modest salt reduction on blood pressure: meta analysis of randomized trials. Implication for public health. J Hum Hypertens 2002; 16: 716-770.

10 MacGregor GA, Fenton S, Alaghband-Zadeh J, Markandu ND, Roulston JE, de Wardener HE. An increase in a circulating inhibitor of $\mathrm{Na}^{+}, \mathrm{K}^{+}$-dependent ATPase: a possible link between salt intake and the development of essential hypertension. Clin Sci (Lond) 1981; 61: 17s-20s.

11 Clough DL, Pamnani MB, Haddy FJ. Decreased myocardial Na+-K+-ATPase activity in one-kidney, one-clip hypertensive rats. Am J Physiol 1983; 245: H244-H251.

12 Hamlyn JM, Levinson PD, Ringel R, Levin PA, Hamilton BP, Blaustein MP, Kowarski AA. Relationships among endogenous digitalis-like factors in essential hypertension. Fed Proc 1985; 44: 2782-2788.

13 Cloix JF, Devynck MA, Meyer P. Chemical and clinical studies of endogenous digitalislike factor in hypertension. Ann NY Acad Sci 1986; 488: 217-227.

14 Kelly RA, O'Hara DS, Mitch WE, Steinman TI, Goldszer RC, Solomon HS, Smith TW. Endogenous digitalis-like factors in hypertension and chronic renal insufficiency. Kidney Int 1986; 30: 723-739.

15 Graves SW, Williams GH. Endogenous digitalis-like natriuretic factors. Annu Rev Med 1987; 38: 433-444.

16 Haddy F, Pamnani M, Clough D. The sodium-potassium pump in volume expanded hypertension. Clin Exp Hypertens 1978-1979; 1: 295-336.

17 Montali U, Balzan S, Ghione S. Characterization of the carrier protein of digoxin-like immunoreactive substance in plasma. J Hypertens 1987; 5: S299-S302.

18 Bagrov AY, Roukoyatkina NI, Pinaev AG, Dmitrieva RI, Fedorova OV. Effects of two endogenous $\mathrm{Na}+, \mathrm{K}(+)$-ATPase inhibitors, marinobufagenin and ouabain, on isolated rat aorta. Eur J Pharmacol 1995; 274: 151-158.

19 Sich B, Kirch U, Tepel M, Zidek W, Schoner W. Pulse pressure correlates in humans with a proscillaridin A immunoreactive compound. Hypertension 1996; 27 : 1073-1078.

20 Yoshika M, Komiyama Y, Konishi M, Akizawa T, Kobayashi T, Date M, Kobatake S, Masuda M, Masaki H, Takahashi $\mathrm{H}$. Novel digitalis-like factor, marinobufotoxin, isolated from cultured $\mathrm{Y}-1$ cells, and its hypertensive effect in rats. Hypertension 2007; 49: 209-214.

21 Aalkjaer C, Mulvany MJ. Effect of ouabain on tone, membrane potential and sodium efflux compared with [3H] ouabain binding in rat resistance vessels. J Physiol 1985; 362: 215-231.

22 Fedorova OV, Anderson DE, Bagrov AY. Plasma marinobufagenin-like and ouabain-like immunoreactivity in adrenocorticotropin-treated rats. Am J Hypertens 1998; 11: 796-802.

23 Tymiak AA, Norman JA, Bolgar M, DiDonato GC, Lee H, Parker WL, Lo LC, Berova N, Nakanishi K, Haber E, Haupert Jr GT. Physicochemical characterization of a ouabain isomer isolated from bovine hypothalamus. Proc Natl Acad Sci USA 1993; 90: 8189-8193.

24 Huang BS, Leenen FH. Brain 'ouabain' mediates the sympathoexcitatory and hypertensive effects of high sodium intake in Dahl salt-sensitive rats. Circ Res 1994; 74: 586-595.

25 Sancho JM. A non-ouabain Na/K ATPase inhibitor isolated from bovine hypothalamus. Its relation to hypothalamic ouabain. Clin Exp Hypertens 1998; 20: 535-542.

26 Houghton BL, Huang C, Johns EJ. Influence of dietary sodium on the blood pressure and renal sympathetic nerve activity responses to intracerebroventricular angiotensin II and angiotensin III in anaesthetized rats. Exp Physiol 2010; 95: 282-295.

27 Collister JP, Hendel MD. Chronic effects of angiotensin II and at1 receptor antagonists in subfornical organ-lesioned rats. Clin Exp Pharmacol Physiol 2005; 32: 462-466.

28 de Champlain J, Karas M, Toal C, Nadeau R, Larochelle P. Effects of antihypertensive therapies on the sympathetic nervous system. Can J Cardiol 1999; 15: 8A-14A.

29 Esler M. Sympathetic nervous activation in essential hypertension: commonly neglected as a therapeutic target, usually ignored as a drug side effect. Hypertension 2010; 55: 1090-1091.

30 Carvalho JJ, Baruzzi RG, Howard PF, Poulter N, Alpers MP, Franco LJ, Marcopito LF, Spooner VJ, Dyer AR, Elliott P. Blood pressure in four remote populations in the INTERSALT Study. Hypertension 1989; 14: 238-246. 
31 Elliott P, Stamler J, Nichols R, Dyer AR, Stamler R, Kesteloot H, Marmot M. Intersalt revisited: further analyses of $24 \mathrm{~h}$ sodium excretion and blood pressure within and across populations. Intersalt Cooperative Research Group. BMJ 1996; 312: 1249-1253.

32 Mancilha-Carvalho JJ, de Oliveira R, Esposito RJ. Blood pressure and electrolyte excretion in the Yanomamo Indians, an isolated population. J Hum Hypertens 1989; 3: 309-314.

33 Robb CA, Davis JO, Johnson JA, Blaine EH, Schneider EG, Baumber JS. Mechanisms regulating the renal excretion of sodium during pregnancy. J Clin Invest 1970; 49: 871-880.

34 Möhring J, Möhring B, Näumann H-J, Philippi A, Homsy E, Orth H, Dauda G, Kazda S. Salt and water balance and renin activity in renal hypertension of rats. Am J Physiol 1975; 228: 1847-1855.

35 Watkins Jr L, Burton JA, Haber E, Cant JR, Smith FW, Barger AC. The reninangiotensin-aldosterone system in congestive failure in conscious dogs. J Clin Invest 1976; 57: 1606-1617.

36 Gill Jr JR, Casper AG. Role of the sympathetic nervous system in the renal response to hemorrhage. J Clin Invest 1969; 48: 915-922.

37 Zambraski EJ, DiBona GF, Kaloyanides GJ. Specificity of neural effect on renal tubular sodium reabsorption. Proc Soc Exp Biol Med 1976; 151: 543-546.

38 DiBona GF. Neurogenic regulation of renal tubular sodium reabsorption. Am J Physio 1977; 233: F73-F81.

39 DeFronzo RA, Cooke CR, Andres R, Faloona GR, Davis PJ. The effect of insulin on renal handling of sodium, potassium, calcium, and phosphate in man. J Clin Invest 1975; 55: 845-855.

40 Hammerman MR, Rogers S, Hansen VA, Gavin III JR. Insulin stimulates Pi transport in brush border vesicles from proximal tubular segments. Am J Physiol 1984; 247: E616-E624.

41 Ohta Y, Tsuchihashi T, Arakawa K, Onaka U, Ueno M. Prevalence and lifestyle characteristics of hypertensive patients with metabolic syndrome followed at an outpatient clinic in Fukuoka, Japan. Hypertens Res 2007; 30: 1077-1082.

42 Strazzullo P, Barbato A, Galletti F, Barba G, Siani A, lacone R, D'Elia L, Russo O, Versiero M, Farinaro E, Cappuccio FP. Abnormalities of renal sodium handling in the metabolic syndrome. Results of the Olivetti Heart Study. J Hypertens 2006; 24: 1633-1639.

43 Swales J. Population advice on salt restriction: the social issues. Am J Hypertens 2000; 13: 2-7.

44 Conlin PR. The dietary approaches to stop hypertension (DASH) clinical trial: implications for lifestyle modifications in the treatment of hypertensive patients. Cardiol Rev 1999; 7: 284-288.

45 He FJ, MacGregor GA. Beneficial effects of potassium on human health. Physiol Plant 2008; 133: 725-735.

46 Wojnowski L, Kersting $\mathrm{U}$, Oberleithner $\mathrm{H}$. Renal potassium bicarbonate release in humans exposed to an acute volume load. Clin Investig 1992; 70: 692-697.

47 Heird WC, Ziegler P, Reidy K, Briefel R. Current electrolyte intakes of infants and toddlers. J Am Diet Assoc 2006; 106: S43-S51.

48 Karppanen H, Karppanen P, Mervaala E. Why and how to implement sodium, potassium, calcium, and magnesium changes in food items and diets? J Hum Hypertens 2005; 19: S10-S19.

49 Krishna GG. Effect of potassium intake on blood pressure. J Am Soc Nephrol 1990; 1: 43-52.

50 Suter PM, Sierro C, Vetter W. Nutritional factors in the control of blood pressure and hypertension. Nutr Clin Care 2002; 5: 9-19.

51 Sacks FM, Obarzanek E, Windhauser MM, Svetkey LP, Vollmer WM, McCullough M, Karanja N, Lin P, Steele P, Proschan MA, Appel LA, Bray GA, Vogt TM, Moore TJ. Rationale and design of the Dietary Approaches to Stop Hypertension trial (DASH). A multicenter controlled-feeding study of dietary patterns to lower blood pressure. Ann Epidemiol 1995; 5: 108-118.

52 Appel LJ, Moore TJ, Obarzanek E, Vollmer WM, Svetkey LP, Sacks FM, Bray GA, Vogt TM, Cutler JA, Windhauser MM, Lin PH, Karanja N. A clinical trial of the effects of dietary patterns on blood pressure. DASH Collaborative Research Group. N Engl J Med 1997; 336: 1117-1124.

53 Fitzsimons JT. Angiotensin, thirst, and sodium appetite. Physiol Rev 1998; 78: 583-686.

54 Meneely GR, Battarbee HD. High sodium-low potassium environment and hypertension. Am J Cardiol 1976; 38: 768-785.

55 Blaustein MP. Sodium ions, calcium ions, blood pressure regulation, and hypertension: a reassessment and a hypothesis. Am J Physiol 1977; 232: C165-C173.

56 Michell AR. Salt appetite, salt intake, and hypertension: a deviation of perspective. Perspect Biol Med 1978; 21: 335-347.

57 Johnston $\mathrm{CI}$, Davis JO, Robb CA, Mackenzie JW. Plasma renin in chronic experimental heart failure and during renal sodium 'escape' from mineralocorticoids. Circ Res 1968; 22: 113-125.

58 Möhring J, Möhring B, Just S. Description of the DOCA escape phenomenon in the rat. Naunyn Schmiedebergs Arch Pharmakol 1970; 266: 406-407.

59 Bricker NS. The control of sodium excretion with normal and reduced nephron populations. The pre-eminence of third factor. Am J Med 1967; 43: 313-321.

60 Bierich JR, Schmidt U. Tubular Na, K-ATPase deficiency, the cause of the congenital renal salt-losing syndrome. Eur J Pediatr 1976; 121: 81-87.

61 Slegers JF, Förster MT. Natriuresis and renal Na-K-ATPase activity in kidneys of normotensive and spontaneously hypertensive rats. Miner Electrolyte Metab 1982; 8: 21-28.

62 Hamlyn JM. Increased levels of a humoral digitalis-like factor in deoxycorticosterone acetate-induced hypertension in the pig. J Endocrinol 1989; 122: 409-420.
63 Doherty JE, Kane JJ. Clinical pharmacology and therapeutics use of digitalis glycosides. Drugs 1973; 6: 182-221.

64 Schreiber V, Kölbel F, Stěpán J, Gregorová I, Pribyl T. Digoxin-like immunoreactivity in the serum of rats with cardiac overload. J Mol Cell Cardiol 1981; 13: 107-110.

65 Pudek MR, Seccombe DW, Whitfield MF, Ling E. Digoxin-like immunoreactivity in premature and full-term infants not receiving digoxin therapy. N Engl J Med 1983; 308: 904-905.

66 Kojima I, Yoshihara S, Ogata E. Involvement of endogenous digitalis-like substance in genesis of deoxycorticosterone-salt hypertension. Life Sci 1982; 30: 1775-1781.

67 Takahashi $\mathrm{H}$, Matsuzawa M, Okabayashi H, Suga K, Ikegaki I, Yoshimura M, Ijichi H. Evidence for a digitalis-like substance in the hypothalamo-pituitary axis in rats. $J$ Hypertens 1986; 4: S317-S320.

68 Takahashi $H$, Matsusawa M, Okabayashi $H$, Suga $K$, Ikegaki I, Nishimura M, Yoshimura M. Endogenous digitalis-like substance in an adult population in Japan. Am J Hypertens 1988; 1: 168S-172S.

69 Komiyama Y, Nishimura N, Dong XH, Hirose S, Kosaka C, Masaki H, Masuda M, Takahashi $\mathrm{H}$. Liquid chromatography mass spectrometric analysis of ouabainlike factor in biological fluid. Hypertens Res 2000; 23: S21-S27.

70 Sagnella GA, Jones JC, Shore AC, Markandu ND, MacGregor GA. Evidence for increased levels of a circulating ouabainlike factor in essential hypertension. Hypertension 1986; 8: 433-437

71 Cloix JF, Crabos M, Meyer P. Recent progress on an endogenous digitalis-like factor in hypertension. J Clin Hypertens 1986; 2: 93-100.

72 Komiyama Y, Mori T, Okuda K, Murakami T, Masuda M, Takahashi H. Production of ouabain-like factors of hypothalamo-pituitary origin, determined by a sensitive ELISA for ouabain, is increased in DOCA-salt hypertensive rats. Pathophysiology 1995; 2: 35-40.

73 Hamlyn JM, Blaustein MP, Bova S, DuCharme DW, Harris DW, Mandel F, Mathews WR, Ludens JH. Identification and characterization of a ouabain-like compound from human plasma. Proc Natl Acad Sci USA 1991; 88: 6259-6263.

74 Komiyama Y, Nishimura N, Munakata M, Mori T, Okuda K, Nishino N, Hirose S, Kosaka C, Masuda M, Takahashi H. Identification of endogenous ouabain in culture supernatant of PC12 cells. J Hypertens 2001; 19: 229-236.

75 Soldin SJ. Digoxin-issues and controversies. Clin Chem 1986; 32: 5-12.

76 Willis JS, Ellory JC. Ouabain sensitivity: diversity and disparities. Curr Top Membr Tramp 1983; 19: 277-280.

77 Yuan CM, Manunta P, Hamlyn JM, Chen S, Bohen E, Yeun J, Haddy FJ, Pamnani MB. Long-term ouabain administration produces hypertension in rats. Hypertension 1993; 22: $178-187$

78 Dostanic I, Paul RJ, Lorenz JN, Theriault S, Van Huysse JW, Lingrel JB. The alpha2-isoform of Na-K-ATPase mediates ouabain-induced hypertension in mice and increased vascular contractility in vitro. Am J Physiol 2005; 288: H477-H485.

79 Holthouser KA, Mandal A, Merchant ML, Schelling JR, Delamere NA, Valdes Jr RR, Tyagi SC, Lederer ED, Khundmiri SJ. Ouabain stimulates Na-K-ATPase through a sodium/hydrogen exchanger-1 (NHE-1)-dependent mechanism in human kidney proximal tubule cells. Am J Physiol 2010; 299: F77-F90.

80 de Wardener HE, Millett J, Holland S, MacGregor GA, Alaghband-Zadeh J. Ouabainlike $\mathrm{Na}^{+}, \mathrm{K}^{+}$-ATPase inhibitor in the plasma of normotensive and hypertensive humans and rats. Hypertension 1987; 10: I-52-I-56.

81 Fedorova OV, Talan MI, Agalakova NI, Lakatta EG, Bagrov AY. Endogenous ligand of alpha (1) sodium pump, marinobufagenin, is a novel mediator of sodium chloridedependent hypertension. Circulation 2002; 105: 1122-1127.

82 Oda M, Kurosawa M, Numazawa S, Tanaka S, Akizawa T, Ito K, Maeda M, Yoshida T. Determination of bufalin-like immunoreactivity in serum of humans and rats by timeresolved fluoroimmunoassay for using a monoclonal antibody. Life Sci 2001; 68: 1107-1117.

83 Padilha AS, Rossoni LV, Xavier FE, Vassallo DV. Ouabain at nanomolar concentration promotes synthesis and release of angiotensin II from the endothelium of the tail vascular bed of spontaneously hypertensive rats. J Cardiovasc Pharmacol 2004; 44: 372-380.

84 Dong XH, Komiyama Y, Nishimura N, Masuda M, Takahashi H. Nanomolar level of ouabain increases intracellular calcium to produce nitric oxide in rat aortic endothelial cells. Clin Exp Pharmacol Physiol 2004; 31: 276-283.

85 Tripodi G, Piscone A, Borsani G, Tisminetzky S, Salardi S, Sidoli A, James P, Pongor S, Bianchi G, Baralle FE. Molecular cloning of an adducin-like protein: evidence of a polymorphism in the normotensive and hypertensive rats of the Milan strain. Biochem Biophys Res Commun 1991; 177: 939-947.

86 Bianchi G, Tripodi MG, Casari G, Torielli L, Cusi D, Barlassina C, Stella P, Zagato L, Barber BR. Alpha-adducin may control blood pressure both in rats and humans. Clin Exp Pharmacol Physiol 1995; 22: S7-S9.

87 Ferrandi M, Minotti E, Salardi S, Florio M, Bianchi G, Ferrari P. Characteristics of a ouabain-like factor from Milan hypertensive rats. J Cardiovasc Pharmacol 1993; 22: S75-S78.

88 Manunta P, Ferrandi M, Messaggio E, Ferrari P. A new antihypertensive agent that antagonizes the prohypertensive effect of endogenous ouabain and adducin. Cardiovasc Hematol Agents Med Chem 2006; 4: 61-66.

89 Ferrari P, Torielli L, Ferrandi M, Padoani G, Duzzi L, Florio M, Conti F, Melloni P, Vesci L, Corsico N, Bianchi G. PST2238: a new antihypertensive compound that antagonizes the long-term pressor effect of ouabain. J Pharmacol Exp Ther 1998; 285: 83-94

90 Ferrari P. Rostafuroxin: an ouabain-inhibitor counteracting specific forms of hypertension. Biochim Biophys Acta 2010; 1802: 1254-1258. 
91 Citterio L, Lanzani C, Manunta P, Bianchi G. Genetics of primary hypertension: the clinical impact of adducin polymorphisms. Biochim Biophys Acta 2010; 1802 1285-1298.

92 Ferrandi M, Barassi P, Molinari I, Torielli L, Tripodi G, Minotti E, Bianchi G, Ferrari P. Ouabain antagonists as antihypertensive agents. Curr Pharm Des 2005; 11: 3301-3305.

93 Staessen JA, Thijs L, Stolarz-Skrzypek K, Bacchieri A, Barton J, Espositi ED, de Leeuw PW, Dłużniewski M, Glorioso N, Januszewicz A, Manunta P, Milyagin V, Nikitin Y, Souček M, Lanzani C, Citterio L, Timio M, Tykarski A, Ferrari P, Valentini G, KaweckaJaszcz K, Bianchi G. Main results of the ouabain and adducin for Specific Intervention on Sodium in Hypertension Trial (OASIS-HT): a randomized placebo-controlled phase2 dose-finding study of rostafuroxin. Trials $2011 ; 12$ : 13-27.

94 Dutta S, Marks BH, Schoener EP. Accumulation of radioactive cardiac glycosides by various brain regions in relation to the dysrhythmogenic effect. Br J Pharmacol 1977; 59: 101-106

95 Kitano S, Morimoto S, Nishibe A, Fukuo K, Hirotani A, Nakahashi T, Yasuda O, Ogihara T. Exogenous ouabain is accumulated in the adrenals and mimics the kinetics of endogenous digitalis-like factor in rats. Hypertens Res 1998; 21: 47-56.

96 DiBartolo V, Balzan S, Pieraccini L, Ghione S, Pegorana S, Biber P, Revoltella R, Montali U. Evidences for an ouabain-like immunoreactive factor in human newborn plasma coeluting with ouabain on HPLC. Life Sci 1995; 57: 1417-1425.

97 Greef K, Wirth KE. Pharmacokinetics of strophanthin glycosides. In Hofmann FB (ed), Handbook of Experimental Pharmacology, Vol 56, pt II. Springer: Berlin, 1981 pp. 57-85.

98 Manunta P, Evans G, Hamilton BP, Gann D, Resau J, Hamlyn JM. A new syndrome with elevated plasma ouabain and hypertension secondary to an adrenocortical tumour (Abstract). J Hypertens 1992; 10: S27.

99 Komiyama Y, Nishimura N, Munakata M, Okuda K, Nishino N, Kosaka C, Masuda M, Mori T, Mstsuda T, Takahashi H. Increases in plasma ouabainlike immunoreactivity during surgical extirpation of pheochromocytoma. Hypertens Res 1999; 22 135-139.

100 Takahashi H, Ihara N, Terano Y, Yamada H, Nishimura M, Nakanishi T, Yamamoto K, Kinoshita Y, Yoshimura M. Ouabain-like immunoreactive substances exist in the hypothalamus and the adrenal medulla in rats. Pathophysiology 1994; 1: 25-28.

101 Yamada H, Naruse M, Naruse K, Demura H, Takahashi H, Yoshimura M, Ochi J. Histological study on ouabain immunoreactivities in the mammalian hypothalamus. Neurosci Lett 1992; 141: 143-146.

102 Takahashi H, Matsuzawa M, Okabayashi H, Suga K, Ikegaki I, Yoshimura M, Ijichi H, Okamura H, Murakami S, Ibata Y. Evidence for a digitalis-like substance in the hypothalamopituitary axis in rats: implications in the central cardiovascular regulation associated with an excess intake of sodium. Jpn Circ J 1987; 51: 1199-1207.

103 Summy-Long JY, Kadekaro M. Role of circumventricular organs (CVO) in neuroendocrine responses: interactions of CVO and the magnocellular neuroendocrine system in different reproductive states. Clin Exp Pharmacol Physiol 2001; 28: 590-601.

104 Yamada H, Ihara N, Takahashi H, Yoshimura M, Sano Y. Distribution of the endogenous digitalis-like substance (EDLS)-containing neurons labeled by digoxin antibody in hypothalamus and three circumventricular organs of dog and macaque. Brain Res 1992; 584: 237-243.

105 Komiyama Y, Mori T, Okuda K, Munakata M, Murakami T, Masuda M, Goto A, Yamada $\mathrm{K}$, Takahashi $\mathrm{H}$. Effects of intracerebroventricular administration of 6-hydroxydopamine on ouabain-like immunoreactivity in plasma and the hypothalamo-pituitary axis in rats. J Hypertens 1996; 14: 447-452.

106 Perrin A, Brasmes B, Chambaz EM, Defaye G. Bovine adrenocortical cells in culture synthesize an ouabain-like compound. Mol Cell Endocrinol 1997; 126: 7-15.

107 Qazzaz HMAM, EI-Masri MA, Valdes RJ. Secretion of a lactonehydrogenated ouabainlike effector of sodium, potassium-adenosinetriphosphatase activity by adrenal cells. Endocrinology 2000; 141: 3200-3209.

108 Belsham DD, Cai F, Cui H, Smukler SR, Salapatek AM, Shkreta L. Generation of a phenotypic array of hypothalamic neuronal cell models to study complex neuroendocrine disorders. Endocrinology 2004; 145: 393-400.

109 Yoshika M, Komiyama Y, Takahashi H. An ouabain-like factor is secreted from immortalized hypothalamic cells in an aldosterone-dependent manner. Neurochem Int 2011; 59: 104-108.

110 Murrell JR, Randall JD, Rosoff J, Zhao JL, Jensen RV, Gullans SR, Haupert Jr GT Endogenous ouabain: upregulation of steroidogenic genes in hypertensive hypothalamus but not adrenal. Circulation 2005; 112: 1301-1308.

111 Lichtstein D, Gati I, Samuelov S, Berson D, Rozeman Y, Landau L, Deutsch J. Identification of digitalis-like compounds in human cataractous lenses. Eur J Biochem 1993; 216: 261-268.

112 Matsukawa M, Akizawa T, Morris JF, Butler Jr VP, Yoshioka M. Marinoic acid, a novel bufadienolide-related substance in the skin of the giant toad, Bufo marinus. Chem Pharm Bull (Tokyo) 1996; 44: 255-257.

113 Hong Z, Chan K, Yeung HW. Simultaneous determination of bufadienolides in the traditional Chinese medicine preparation, liu-shen-wan, by liquid chromatography. I Pharm Pharmacol 1992; 44: 1023-1026.

114 Fedorova OV, Bagrov AY. Inhibition of Na/K-ATPase from rat aorta by two endogenous $\mathrm{Na} / \mathrm{K}$ pump inhibitors, ouabain and marinobufagenin. Evidence of interaction with different $\alpha$-subunit isoforms. Am J Hypertens 1997; 10: 929-935.

115 Fedorova OV, Kolodkin NI, Agalakova NI, Lakatta EG, Bagrov AY. Marinobufagenin, an endogenous $\alpha 1$ sodium pump ligand, in hypertensive Dahl salt-sensitive rats. Hypertension 2001; 37: 462-466.

116 Pamnani MB, Chen S, Yuan CM, Haddy FJ. Chronic blood pressure effects of bufalin, a sodium-potassium ATPase inhibitor in rats. Hypertension 1994; 23: I-106-I-109.
117 Bagrov AY, Feodorova OV, Dmitrieva RI, French AW, Anderson DE. Plasma marinobufagenin-like and ouabain-like immunoreactivity during saline volume expansion in anaesthetized dogs. Cardiovasc Res 1996; 31: 296-305.

118 Bagrov AY, Feodorova OV, Austin-Lane JL, Dimitrieva RI, Andersen DE. Endogenous marinobufagenin-like immunoreactive factor and $\mathrm{Na}_{-}, \mathrm{K}_{-}$ATPase inhibition during voluntary hypoventilation. Hypertension 1995; 26: 781-788.

119 Fedorova OV, Kolodkin NI, Agalakova NI, Lakatta EG, Bagrov AY. Marinobufagenin, an endogenous $\alpha 1$ sodium pump ligand, in hypertensive Dahl salt-sensitive rats. Hypertension 2001; 37: 462-466.

120 Fedorova OV, Kolodkin NI, Agalakova NI, Namikas AR, Bzhelyansky A, St-Louis J, Lakatta EG, Bagrov AY. Antibody to marinobufagenin lowers blood pressure in pregnant rats on a high $\mathrm{NaCl}$ intake. J Hypertens 2005; 23: 835-842.

121 Komiyama Y, Dong XH, Nishimura N, Masaki H, Yoshika M, Masuda M, Takahashi H. A novel endogenous digitalis, telocinobufagin, exhibits elevated plasma levels in patients with terminal renal failure. Clin Biochem 2005; 38: 36-45.

122 Yoshika M, Komiyama Y, Takahashi H. Isolation of marinobufotoxin from the supernatant of cultured PC12 cells. Clin Exp Pharmacol Physiol 2011; 38: 334-337.

123 Dmitrieva RI, Bagrov AY, Lalli E, Sassone-Corsi P, Stocco DM, Doris PA. Mammalian bufadienolide is synthesized from cholesterol in the adrenal cortex by a pathway that is independent of cholesterol side-chain cleavage. Hypertension 2000; 36: 442-448.

124 Lichtstein D, Steinitz M, Gati I, Samuelov S, Deutsch J, Orly J. Biosynthesis of digitalis-like compounds in rat adrenal cells: hydroxycholesterol as possible precursor. Life Sci 1998; 62: 2109-2126.

125 Manunta P, Hamilton BP. Hamlyn JM. Salt intake and depletion increase circulating levels of endogenous ouabain in normal men. Am J Physiol 2006; 290: R553-R559.

126 Yamada K, Goto A, Nagoshi H, Terano Y, Omata M. Elevation of ouabain-like compound levels with hypertonic sodium chloride load in rat plasma and tissues. Hypertension 1997; 30: 94-98.

127 Takahashi H, Matsusawa M, Suga K, Ikegaki I, Nishimura M, Yoshimura M, Ihara N, Yamada H, Sano Y. Hypothalamic digitalis-like substance is released with sodiumloading in rats. Am J Hypertens 1988; 1: 146-151.

128 Leenen FHH, Harmsen E, Yu H. Dietary sodium and central vs. peripheral ouabain-like activity in Dahl salt-sensitive vs. salt-resistant rats. Am J Physiol 1994; 267: H1916-H1920.

129 Bauer N, Müller-Ehmsen J, Krämer U, Hambarchian N, Zobel C, Schwinger RHG, Neu H, Kirch U, Grünbaum EG, Schoner W. Ouabain-like compound changes rapidly upon physical exercise in man and dog: effects of -blockade and ACE-inhibition. Hypertension 2005; 45: 1024-1028.

130 Bagrov AY, Fedorova OV, Dmitrieva RI, Howald WN, Hunter AP, Kuznetsova EA, Shpen VM. Characterization of a urinary bufodienolide $\mathrm{Na}, \mathrm{K}$-ATPase inhibitor in patients after acute myocardial infarction. Hypertension 1998; 31: 1097-1103.

131 Bagrov AY, Fedorova OV, Maslova MN, Roukoyatkina NI, Ukhanova MA, Zhabko EP. Endogenous plasma Na,K-ATPase inhibitory activity and digoxin-like immunoreactivity after acute myocardial infarction. Cardiovasc Res 1991; 25: 371-377.

132 Hamlyn JM, Hamilton BP, Manunta P. Endogenous ouabain, sodium balance and blood pressure: a review and a hypothesis. J Hypertens 1996; 14: 151-167.

133 Masugi F, Ogihara T, Hasegawa T, Sagakuchi K, Kumahara Y Normalization of high plasma level of ouabain-like immunoreactivity in primary aldosteronism after removal of adenoma. J Hum Hypertens 1988; 2: 17-20.

134 Rossi GP, Manunta P, Hamlyn JM, Pavan E, De Toni R, Semplicini A, Pessina AC. Immunoreactive endogenous ouabain in primary hyperaldosteronism and essential hypertension: relationship with plasma renin, aldosterone and blood pressure levels. J Hypertens 1995; 13: 1181-1191.

135 Gottlieb SS, Rogowski AC, Weinberg M, Krichten CM, Hamilton BC, Hamlyn JM. Elevated concentrations of endogenous ouabain in patients with congestive heart failure. Circulation 1992; 86: 420-425.

136 Balzan S, Neglia D, Ghione S, D'Urso G, Baldacchino M, Montali U, L'Abbate A Increased circulating levels of ouabain-like factor in patients with asymptomatic left ventricular dysfunction. Eur J Heart Fail 2001; 3: 165-171.

137 Delva P, Capra C, Degan M, Minuz P, Covi G, Milan L, Steele A, Lechi A. High plasma levels of a ouabain-like factor in normal pregnancy and in pre-eclampsia. Eur J Clin Invest 1989; 19: 95-100.

138 Gregoire I, Roth D, Siegenthaler G, Fievet P, el Esper N, Favre H, Fournier A. A ouabain-displacing factor in normal pregnancy, pregnancy-induced hypertension and pre-eclampsia. Clin Sci (Lond) 1988; 74: 307-310.

139 Poston L, Sewell R, Wilkinson S, Richardson P, Williams R, Clarkson E, MacGregor G, DeWardener $\mathrm{H}$. Evidence for a circulating sodium transport inhibitor in essential hypertension. BMJ 1981; 282: 847-849.

140 Balzan S, Nicolini G, lervasi A, Di Cecco P, Fommei E. Endogenous ouabain and acute salt loading in low-renin hypertension. Am J Hypertens 2005; 18: 9006-9009.

141 Hamlyn JM, Ringel R, Schaeffer J, Levinson PD, Hamilton BP, Kowarski AA, Blaustein MP. A circulating inhibitor of $\mathrm{Na}^{+}-\mathrm{K}^{+}$-ATPase associated with essential hypertension. Nature 1982; 300: 650-652.

142 Moreth K, Kuske R, Renner D, Schoner W. Blood pressure in essential hypertension correlates with the concentration of a circulating inhibitor of the sodium pump. Klin Wochenschr 1986; 64: 239-244.

143 Huang L, Li H, Xie Z. Ouabain-induced hypertrophy in cultured cardiac myocytes is accompanied by changes in expression of several late response genes. $\mathrm{J} \mathrm{Mol} \mathrm{Cell}$ Cardiol 1997; 29: 429-437.

144 Komiyama Y, Kimura Y, Nishimura N, Hara K, Mori T, Okuda K, Munakata M, Masuda $\mathrm{M}$, Murakami T, Takahashi $\mathrm{H}$. Vasodepressor effects of exercise are accompanied by reduced circulating ouabainlike immunoreactivity and normalization of nitric oxide synthesis. Clin Exp Hypertens 1997; 19: 363-372. 
145 Iyoda I, Takahashi H, Lee LC, Okajima H, Inoue A, Sasaki S, Takeda K, Yoshimura M, Ijichi H. Cardiovascular and sympathetic responses to ouabain injected into the hypothalamus in rats. Cardiovasc Res 1986; 20: 294-298.

146 Takahashi H, Okabayashi H, Matsuzawa M, Suga K, Ikegaki I, Yoshimura M, Ijichi H. Centrally induced vasopressor responses to ouabain in DOCA-salt hypertensive rats. Cardiovasc Res 1987; 21: 439-446.

147 Takahashi H, Iyoda I, Takeda K, Sasaki S, Okajima H, Yamasaki H, Yoshimura M, Ijichi $\mathrm{H}$. Centrally-induced vasopressor responses to sodium-potassium adenosine triphosphatase inhibitor, ouabain, may be mediated via angiotensin II in the anteroventral third ventricle in the brain. Jpn Circ J 1984; 48: 1243-1250.

148 Huang BS, Leenen FH. Brain ouabain and central effects of dietary sodium in spontaneously hypertensive rats. Circ Res 1992; 70: 430-443.

149 Parati G, Schumacher H, Bilo G, Mancia G. Evaluating 24-h antihypertensive efficacy by the smoothness index: a meta-analysis of an ambulatory blood pressure monitoring database. J Hypertens 2010; 28: 2177-2183.

150 Souza LM, Riera R, Saconato H, Demathé A, Atallah AN. Oral drugs for hypertensive urgencies: systematic review and meta-analysis. Sao Paulo Med J 2009; 127: 366-372.

151 Baguet JP, Robitail S, Boyer L, Debensason D, Auquier P. A meta-analytical approach to the efficacy of antihypertensive drugs in reducing blood pressure. Am J Cardiovasc Drugs 2005; 5: 131-140.

152 Funder JW, Mihailidou AS. Aldosterone and mineralocorticoid receptors: clinical studies and basic biology. Mol Cell Endocrinol 2009; 301: 2-6.

153 Shah RV, Desai AS, Givertz MM. The effect of renin-angiotensin system inhibitors on mortality and heart failure hospitalization in patients with heart failure and preserved ejection fraction: a systematic review and meta-analysis. J Card Fail 2010; 16: 260-267.

154 Braga MF, Leiter LA. Role of renin-angiotensin system blockade in patients with diabetes mellitus. Am J Cardiol 2009; 104: 835-839.

155 Nakao K, Hirata M, Oba K, Yasuno S, Ueshima K, Fujimoto A, Ogihara T, Saruta T. Role of diabetes and obesity in outcomes of the candesartan antihypertensive survival evaluation in Japan (CASE-J) trial. Hypertens Res 2010; 33: 600-606.

156 Narumi H, Takano H, Shindo S, Fujita M, Mizuma H, Kuwabara Y, Komuro I. Effects of valsartan and amlodipine on cardiorenal protection in Japanese hypertensive patients: the Valsartan Amlodipine Randomized Trial. Hypertens Res 2011; 34: 62-69.

157 Bethel MA, Holman R, Haffner SM, Califf RM, Huntsman-Labed A, Hua TA, McMurray $J$. Determining the most appropriate components for a composite clinical trial outcome. Am Heart J 2008; 156: 633-640.

158 Shiga T, Kasanuki H, Hagiwara N, Sumiyoshi T, Honda T, Haze K, Takagi A, Kawana $\mathrm{M}$, Origasa $\mathrm{H}$, Ogawa $\mathrm{H}$. Angiotensin receptor blocker-based therapy and cardiovascular events in hypertensive patients with coronary artery disease and impaired renal function. Blood Press 2010; 19: 359-365.

159 Hoogwerf BJ. Renin-angiotensin system blockade and cardiovascular and renal protection. Am J Cardiol 2010; 105: 30A-35A.

160 Antonaccio MJ, Rubin B, Horovitz ZP, Laffan RJ, Goldberg ME, High JP, Harris DN, Zaidi I. Effects of chronic treatment with captopril (SQ 14,225), an orally active inhibitor of angiotensin I-converting enzyme, in spontaneously hypertensive rats. Jpn J Pharmacol 1979; 29: 285-294.

161 Giudicelli JF, Freslon JL, Glasson S, Richer C. Captopril and hypertension development in the SHR. Clin Exp Hypertens 1980; 2: 1083-1096.

162 Marieb NJ, Mulrow PJ. Role of the renin-angiotensin system in the regulation of aldostereone secretion in the rat. Endocrinology 1965; 76: 657-664.

163 Ganguly A, Weinberger MH. Low renin hypertension: a current review of definitions and controversies. Am Heart J 1979; 98: 642-652.

164 Woods JW, Pittman AW, Pulliam CC, Werk Jr EE, Waider W, Allen CA. Renin profiling in hypertension and its use in treatment with propranolol and chlorthalidone. $N$ Engl J Med 1976; 294: 1137-1143.

165 Brunner HR, Gavras H, Waeber B, Kershaw GR, Turini GA, Vukovich RA, McKinstry DN, Gavras I. Oral angiotensin-converting enzyme inhibitor in long-term treatment of hypertensive patients. Ann Intern Med 1979; 90: 19-23.

166 Minami J, Ishimitsu T, Matsuoka H. Is there overlap in blood-pressure response to the blockers of the renin-angiotensin system between lower and higher renin subjects? Am J Hypertens 2008; 21: 130-131.

167 Weinberger MH, White WB, Ruilope LM, MacDonald TM, Davidson RC, Roniker B, Patrick JL, Krause SL. Effects of eplerenone versus losartan in patients with low-renin hypertension. Am Heart J 2005; 150: 426-433.

168 Cozzari C, Angeletti PU, Lazar J, Orth H, Gross F. Separation of isorenin activity from nerve growth factor (NGF) activity in mouse submaxillary gland extracts. Biochem Pharmacol 1973; 22: 1321-1327.

169 Hirose S, Ohsawa T, Inagami T, Murakami K. Brain renin from bovine anterior pituitary. Isolation and properties. J Biol Chem 1982; 257: 6316-6321.

170 Tada M, Fukamizu A, Seo MS, Takahashi S, Murakami K. Renin expression in the kidney and brain is reciprocally controlled by captopril. Biochem Biophys Res Commun 1989; 159: 1065-1071.

171 Sweet CS, Columbo JM, Gaul SL. Central antihypertensive effects of inhibitors of the renin-angiotensin system in rats. Am J Physiol 1976; 231: 1794-1799.

172 Hoffman WE, Weet JF, Phillips MI, Schmid PG. Central effects of angiotensin II in water and saline loaded rats. Neuroendocrinology 1979; 28: 289-296.

173 Schölkens BA, Jung W, Rascher W, Schömig A, Ganten D. Brain angiotensin II stimulates release of pituitary hormones, plasma catecholamines and increases blood pressure in dogs. Clin Sci (Lond) 1980; 59: 53s-56s.
174 Mann JF, Rascher W, Schömig A, Buu T, Kuchel O, Boucher R, Genest J. Contribution of the sympathetic nervous system to the centrally-induced pressor action of angiotensin II in rats. Clin Exp Pharmacol Physiol 1982; 9: 193-201

175 Sumners C, Phillips MI. Central injection of angiotensin II alters catecholamine activity in rat brain. Am J Physiol 1983; 244: R257-R263.

176 Nishimura M, Nanbu A, Ohtsuka K, Takahashi H, Iwai N, Kinoshita M, Yoshimura M. Sodium intake regulates renin gene expression differently in the hypothalamus and kidney of rats. J Hypertens 1997; 15: 509-516.

177 Nishimura M, Ohtsuka K, Takahashi H, Yoshimura M. Role of FMRFamide-activated brain sodium channel in salt-sensitive hypertension. Hypertension 2000; 35: 443-450.

178 Gomez-Sanchez EP, Ahmad N, Romero DG, Gomez-Sanchez CE. Is aldosterone synthesized within the rat brain? Am J Physiol 2005; 288: E342-E346.

179 Huang BS, Cheung WJ, Wang H, Tan J, White RA, Leenen FH. Activation of brain renin-angiotensin-aldosterone system by central sodium in Wistar rats. Am J Physiol 2006; 291: H1109-H1117.

180 Gomez-Sanchez EP. Intracerebroventricular infusion of aldosterone induces hypertension in rats. Endocrinology 1986; 118: 819-823.

181 Atarashi K, Matsuoka H, Takagi M, Yamada K, Hirata Y, Hayakawa H, Sugimoto T. Effects of intracerebroventricular infusion of aldosterone on blood pressure and sodium and potassium concentrations in cerebral spinal fluid in rats. Clin Exp Hypertens A 1988; 10(Suppl 1): 317-322.

182 Takahashi H, Matsusawa M, Ikegaki I, Nishimura M, Yoshimura M, Yamada H, Sano Y. Brain renin-angiotensin system and the hypothalamic, digitalis-like $\mathrm{Na}+, \mathrm{K}+-$-ATPase inhibitor in rats. Clin Exp Hypertens A 1988; 10: 1285-1287.

183 Sasaki S, Takeda K, Okajima H, Takahashi H, Yoshimura M, Nakagawa M, Ijichi H. Pressor responses to intracisternal injection of hypertonic $\mathrm{NaCl}$ in rats. $J$ Cardiovasc Pharmacol 1984; 6: 349-354.

184 Buñag RD, Miyajima E. Sympathetic hyperactivity elevates blood pressure during acute cerebroventricular infusions of hypertonic salt in rats. J Cardiovasc Pharmacol 1984; 6: 844-851.

185 Kawano Y, Ferrario CM. Neurohormonal characteristics of cardiovascular response due to intraventricular hypertonic $\mathrm{NaCl}$. Am J Physiol 1984; 247: $\mathrm{H} 422-\mathrm{H} 428$.

186 Sakamoto M, Nishimura M, Takahashi H. Brain atrial natriuretic peptide family abolishes cardiovascular haemodynamic alterations caused by hypertonic saline in rats. Clin Exp Pharmacol Physiol 1999; 26: 684-690.

187 Saper CB, Hurley KM, Moga MM, Holmes HR, Adams SA, Leahy KM, Needleman P. Brain natriuretic peptides: differential localization of a new family of neuropeptides. Neurosci Lett 1989; 96: 29-34.

188 Herman JP, Langub Jr MC, Watson Jr RE. Localization of C-type natriuretic peptide mRNA in rat hypothalamus. Endocrinology 1993; 133: 1903-1906.

189 DiBona GF. Neural regulation of renal tubular sodium reabsorption and renin secretion. Fed Proc 1985; 44: 2816-2822.

190 Kato K, Shirasaka T, Kunitake T, Hanamori T, Kannan H. Participation of arterial baroreceptors input and peripheral vasopressin in the suppression of renal sympathetic nerve activity induced by central salt loading in conscious rats. J Auton Nerv Syst 1999; 76: 83-92.

191 Ericson AC, Sjöquist M. Efferent renal nerve activity during intracarotid and intracerebroventricular infusions of hypertonic sodium chloride solutions and isotonic volume expansion in the rat. Acta Physiol Scand 1982; 114: 9-15.

192 May CN, McAllen RM. Brain angiotensinergic pathways mediate renal nerve inhibition by central hypertonic $\mathrm{NaCl}$ in conscious sheep. Am J Physiol 1997; 272: R593-R600.

193 Takahashi H, Matsuzawa M, Okabayashi H, Suga K, Ikegaki I, Yoshimura M, Ijichi H. Evidence for a digitalis-like substance in the hypothalamo-pituitary axis in rats. $J$ Hypertens 1986; 4: S317-S320.

194 Heck GL, Mierson S, DeSimone JA. Salt taste transduction occurs through an amiloride-sensitive sodium transport pathway. Science 1984; 223: 403-405.

195 Garty H, Palmer LG. Epithelial sodium channels: function, structure, and regulation. Physiol Rev 1997; 77: 359-396.

196 Nishimura M, Ohtsuka K, Nanbu A, Takahashi H, Yoshimura M. Benzamil blockade of brain $\mathrm{Na}^{+}$channels averts $\mathrm{Na}^{(+)}$-induced hypertension in rats. Am J Physiol 1998; 274: R635-R644.

197 Wang H, Huang BS, Leenen FH. Brain sodium channels and ouabainlike compounds mediate central aldosterone-induced hypertension. Am J Physiol 2003; 285: H2516-H2523.

198 Amin MS, Wang HW, Reza E, Whitman SC, Tuana BS, Leenen FH. Distribution of epithelial sodium channels and mineralocorticoid receptors in cardiovascular regulatory centers in rat brain. Am J Physiol 2005; 289: R1787-R1797.

199 Amin MS, Reza E, Wang H, Leenen FH. Sodium transport in the choroid plexus and salt-sensitive hypertension. Hypertension 2009; 54: 860-867.

200 Wang HW, Amin MS, El-Shahat E, Huang BS, Tuana BS, Leenen FH. Effects of central sodium on epithelial sodium channels in rat brain. Am J Physiol 2010; 299: R222-R233.

201 Huang BS, Leenen FH. Brain amiloride-sensitive Phe-Met-Arg-Phe-NH(2)—gated $\mathrm{Na}(+)$ channels and $\mathrm{Na}(+)$-induced sympathoexcitation and hypertension. Hypertension 2002; 39: 557-561.

202 Huang BS, Leenen FH. Blockade of brain mineralocorticoid receptors or $\mathrm{Na}+$ channels prevents sympathetic hyperactivity and improves cardiac function in rats post-MI. Am J Physiol 2005; 288: H2491-H2497.

203 Gomez-Sanchez EP, Gomez-Sanchez CE. Effect of central amiloride infusion on mineralocorticoid hypertension. Am J Physiol 1994; 267: E754-E758. 
204 Qadri F, Edling O, Wolf A, Gohlke P, Culman J, Unger T. Release of angiotensin in the paraventricular nucleus in response to hyperosmotic stimulation in conscious rats: a microdialysis study. Brain Res 1994; 637: 45-49.

205 Nishimura M, Takahashi H, Yoshimura M. Upregulation of the brain renin-angiotensin system in rats with chronic renal failure. Acta Physiol (Oxf) 2007; 189: 369-377.

206 Stromstedt M, Waterman MR. Messenger RNAs encoding steroidogenic enzymes are expressed in rodent brain. Brain Res Mol Brain Res 1995; 34: 75-88.

207 Han F, Ozawa H, Matsuda KI, Lu H, De Kloet ER, Kawata M. Changes in the expression of corticotrophin-releasing hormone, mineralocorticoid receptor and glucocorticoid receptor mRNAs in the hypothalamic paraventricular nucleus induced by fornix transection and adrenalectomy. J Neuroendocrinol 2007; 19: 229-238.

208 Yu L, Romero DG, Gomez-Sanchez CE, Gomez-Sanchez EP. Steroidogenic enzyme gene expression in the human brain. Mol Cell Endocrinol 2002; 190: 9-17.

209 Gomez-Sanchez EP, Gomez-Sanchez CM, Plonczynski M, Gomez-Sanchez CE. Aldosterone synthesis in the brain contributes to Dahl salt-sensitive rat hypertension. Exp Physiol 2010; 95: 120-130.

210 Huang BS, White RA, Ahmad M, Jeng AY, Leenen FH. Central infusion of aldosterone synthase inhibitor prevents sympathetic hyperactivity and hypertension by central $\mathrm{Na}^{+}$ in Wistar rats. Am J Physiol 2008; 295: R166-R172.

211 Zhang ZH, Yu Y, Kang YM, Wei SG, Felder RB. Aldosterone acts centrally to increase brain renin-angiotensin system activity and oxidative stress in normal rats. Am J Physiol 2008; 294: H1067-H1074.

212 Fukiyama K, McCubbin JW, Page IH. Chronic hypertension elicited by infusion of angiotensin into vertebral arteries of unanaesthetized dogs. Clin Sci 1971; 40: 283-291.

213 Li Q, Dale WE, Hasser EM, Blaine EH. Acute and chronic angiotensin hypertension: neural and nonneural components, time course, and dose dependency. Am J Physio 1996; 271: R200-R207.

214 Fink GD. Long-term sympatho-excitatory effect of angiotensin II: a mechanism of spontaneous and renovascular hypertension. Clin Exp Pharmacol Physiol 1997; 24 91-95.

215 Huang BS, Ahmadi S, Ahmad M, White RA, Leenen FH. Central neuronal activation and pressor responses induced by circulating ANG II: role of the brain aldosterone'ouabain' pathway. Am J Physiol 2010; 299: H422-H430.

216 Xue B, Beltz TG, Yu Y, Guo F, Gomez-Sanchez CE, Hay M, Johnson AK. Central interactions of aldosterone and angiotensin II in aldosterone- and angiotensin IIinduced hypertension. Am J Physiol 2011; 300: H555-H564.

217 Kang YM, Ma Y, Zheng JP, Elks C, Sriramula S, Yang ZM, Francis J. Brain nuclear factor-kappa $B$ activation contributes to neurohumoral excitation in angiotensin IIinduced hypertension. Cardiovasc Res 2009; 82: 503-512.

218 Fuller PJ, Young MJ. Mechanisms of mineralocorticoid action. Hypertension 2005; 46: 1227-1235.

219 Funder JW. Aldosterone, mineralocorticoid receptors and vascular inflammation. $\mathrm{Mol}$ Cell Endocrinol 2004; 217: 263-269.

220 Alzamora R, Michea L, Marusic ET. Role of 11ß-hydroxysteroid dehydrogenase in nongenomic aldosterone effects in human arteries. Hypertension 2000; 35: 1099-1104.

221 Araki S, Hirooka Y, Kishi T, Yasukawa K, Utsumi H, Sunagawa K. Olmesartan reduces oxidative stress in the brain of stroke-prone spontaneously hypertensive rats assessed by an in vivo ESR method. Hypertens Res 2009; 32: 1091-1096.

222 Lu N, Helwig BG, Fels RJ, Parimi S, Kenney MJ. Central Tempol alters basal sympathetic nerve discharge and attenuates sympathetic excitation to central II ANG. Am J Physiol 2004; 287: H2626-H2633.

223 Yu Y, Wei SG, Zhang ZH, Gomez-Sanchez E, Weiss RM, Felder RB. Does aldosterone upregulate the brain renin-angiotensin system in rats with heart failure? Hypertension 2008; 51: 727-733.

224 Hirooka Y. Oxidative stress in the cardiovascular center has a pivotal role in the sympathetic activation in hypertension. Hypertens Res 2011 ; 34: 407-412.

225 Taylor AA. Autonomic control of cardiovascular function: clinical evaluation in health and disease. J Clin Pharmacol 1994; 34: 363-374.

226 Schreihofer AM, Ito S, Sved AF. Brain stem control of arterial pressure in chronic arterial baroreceptor-denervated rats. Am J Physiol 2005; 289: R1746-R1755.

227 Di Rienzo M, Castiglioni P, Parati G, Mancia G, Pedotti A. Effects of sino-aortic denervation on spectral characteristics of blood pressure and pulse interval variability: a wide-band approach. Med Biol Eng Comput 1996; 34: 133-141.

228 Lovallo WR. Cardiovascular reactivity: mechanisms and pathways to cardiovascular disease. Int J Psychophysiol 2005; 58: 119-132.

229 Mancia G, Grassi G, Parati G, Pomidossi G, Saino A, Malaspina D, Gregorini L, Zanchetti A. Control of circulation by arterial baroreceptors and cardiopulmonary receptors in hypertension. J Cardiovasc Pharmacol 1986; 8: S82-S88.

230 Heesch CM, Crandall ME, Turbek JA. Converting enzyme inhibitors cause pressureindependent resetting of baroreflex control of sympathetic outflow. Am J Physio 1996; 270: R728-R737.

231 Takahashi H, Takeda K, Ashizawa H, Inoue A, Yoneda S, Yoshimura M, Ijichi H. Centrally induced cardiovascular and sympathetic responses to hydrocortisone in rats. Am J Physiol 1983; 245: H1013-H1018.

232 Geerling JC, Loewy AD. 11 beta-hydroxysteroid dehydrogenase 2 vs. transgene: discrepant loci of expression in the adult brain. Am J Physiol 2007; 293: F440-F441.

233 Edwards CR, Burt D, Stewart PM. The specificity of the human mineralocorticoid receptor: clinical clues to a biological conundrum. J Steroid Biochem 1989; 32: 213-216.

234 Moguilewsky M, Raynaud JP. Evidence for a specific mineralocorticoid receptor in rat pituitary and brain. J Steroid Biochem 1980; 12: 309-314.
235 Geerling JC, Kawata M, Loewy AD. Aldosterone-sensitive neurons in the rat central nervous system. J Comp Neurol 2006; 494: 515-527.

236 Robson AC, Leckie CM, Seckl JR, Holmes MC. 11 Beta-hydroxysteroid dehydrogenase type 2 in the postnatal and adult rat brain. Brain Res Mol Brain Res 1998; 61: $1-10$.

237 Takahashi H, Ashizawa H, Takeda KU, Yoneda S, Yoshimura M, ljichi H. Central vasopressor responses to conjugated estrogens in rats may be mediated via a reninangiotensin system in the brain. J Pharmacol Exp Ther 1982; 222: 726-730.

238 Widgren B, Berglund G, Andersson OK. Side effects in long term treatment with hydralazine. Acta Medica Scandinavica-Supplementum 1986; 714: 193-196.

239 Palma-Gámiz JL. High blood pressure and calcium antagonism. Cardiology 1997; 88(Suppl 1): 39-46.

240 Perry Jr HM. The evolution of antihypertensive therapy. Am J Cardiol 1985; 56 : $75 \mathrm{H}-80 \mathrm{H}$.

241 Velasco M, Rodriguez I. Appropriate choice of antihypertensive therapy. J Hum Hypertens 1996; 10: S77-S80.

242 ALLHAT Officers and Coordinators for the ALLHAT Collaborative Research Group. The Antihypertensive and Lipid-Lowering Treatment to Prevent Heart Attack Trial. Major outcomes in high-risk hypertensive patients randomized to angiotensin-converting enzyme inhibitor or calcium channel blocker vs diuretic: the Antihypertensive and Lipid-Lowering Treatment to Prevent Heart Attack Trial (ALLHAT). JAMA 2002; 288: 2981-2997.

243 Cohn JN, Anand IS, Latini R, Masson S, Chiang YT, Glazer R. Sustained reduction of aldosterone in response to the angiotensin receptor blocker valsartan in patients with chronic heart failure: results from the Valsartan Heart Failure Trial. Circulation 2003; 108: 1306-1309.

244 Dahlöf B, Sever PS, Poulter NR, Wedel H, Beevers DG, Caulfield M, Collins R, Kjeldsen SE, Kristinsson A, Mclnnes GT, Mehlsen J, Nieminen M, O'Brien E, Ostergren J. Prevention of cardiovascular events with an antihypertensive regimen of amlodipine adding perindopril as required versus atenolol adding bendroflumethiazide as required, in the Anglo-Scandinavian Cardiac Outcomes Trial-Blood Pressure Lowering Arm (ASCOT-BPLA): a multicentre randomised controlled trial. Lancet 2005; 366: 895-906.

245 Kintscher U. ONTARGET, TRANSCEND, and PRoFESS: new-onset diabetes, atrial fibrillation, and left ventricular hypertrophy. J Hypertens 2009; 27: S36-S39.

246 Thames MD. Contribution of cardiopulmonary baroreceptors to the control of the kidney. Fed Proc 1978; 37: 1209-1213.

247 Burnier M, Brunner HR. Neurohormonal consequences of diuretics in different cardiovascular syndromes. Eur Heart J 1992; 13: S28-S33.

248 Carretta R, Fabris B, Tonutti L, Bellini G, Battilana G, Bianchetti A, Campanacci L. Effect of indapamide on the baroreceptor reflex in essential hypertension. Eur J Clin Pharmacol 1983; 24: 579-583.

249 Maxwell MH, Brachfeld J, Itskovitz H, Lunn JA, Moser M, Zawada ET. Blood pressure lowering and potassium conservation by triamterene-hydrochlorothiazide and amiloride-hydrochlorothiazide in hypertension. Clin Pharmacol Ther 1985; 37: 61-65.

250 Padilla MC, Armas-Hernández MJ, Hernández RH, Israili ZH, Valasco M. Update of diuretics in the treatment of hypertension. Am J Ther 2007; 14: 154-160.

251 Giacchetti G, Turchi F, Boscaro M, Ronconi V. Management of primary aldosteronism: its complications and their outcomes after treatment. Curr Vasc Pharmacol 2009; 7: 244-249.

252 Sepehrdad R, Frishman WH, Stier Jr CT, Sica DA. Direct inhibition of renin as a cardiovascular pharmacotherapy: focus on aliskiren. Cardiol Rev 2007; 15: 242-256.

253 Julius S. Blood pressure lowering only or more? Has the jury reached its verdict? Am J Cardiol 2007; 100: 32J-37J.

254 Dzau V. The cardiovascular continuum and renin-angiotensin-aldosterone system blockade. J Hypertens 2005; 23: S9-S17.

255 Naritomi H, Fujita T, Ito S, Ogihara T, Shimada K, Shimamoto K, Tanaka H, Yoshiike N. Efficacy and safety of long-term losartan therapy demonstrated by a prospective observational study in Japanese patients with hypertension: the Japan Hypertension Evaluation with Angiotensin II Antagonist Losartan Therapy (J-HEALTH) study. Hypertens Res 2008; 31: 295-304.

256 Zhang J, Leenen FH. AT(1) receptor blockers prevent sympathetic hyperactivity and hypertension by chronic ouabain and hypertonic saline. Am J Physiol 2001; 280: $\mathrm{H} 1318-\mathrm{H} 1323$

257 Culman J, von Heyer C, Piepenburg B, Rascher W, Unger T. Effects of systemic treatment with irbesartan and losartan on central responses to angiotensin II in conscious, normotensive rats. Eur J Pharmacol 1999; 367: 255-265.

258 Mehdi UF, Adams-Huet B, Raskin P, Vega GL, Toto RD. Addition of angiotensin receptor blockade or mineralocorticoid antagonism to maximal angiotensin-converting enzyme inhibition in diabetic nephropathy. J Am Soc Nephrol 2009; 20: 2641-2650.

259 Schmieder RE. Optimizing therapeutic strategies to achieve renal and cardiovascular risk reduction in diabetic patients with angiotensin receptor blockers. J Hypertens 2005; 23: 905-911.

260 Fukui T, Rahman M, Hayashi K, Takeda K, Higaki J, Sato T, Fukushima M, Sakamoto J, Morita S, Ogihara T, Fukiyama K, Fujishima M, Saruta T. Candesartan Antihypertensive Survival Evaluation in Japan (CASE-J) trial of cardiovascular events in highrisk hypertensive patients: rationale, design, and methods. Hypertens Res 2003; 26: 979-990.

261 Hayashi K, Saruta T, Goto Y, Ishii M. Impact of renal function on cardiovascular events in elderly hypertensive patients treated with efonidipine. Hypertens Res 2010; 33: 1211-1220.

262 Ohishi M, Takeya Y, Tatara Y, Yamamoto K, Onishi M, Maekawa Y, Kamide K, Rakugi H. Strong suppression of the renin-angiotensin system has a renal-protective effect in 
hypertensive patients: high-dose ARB with ACE inhibitor (Hawaii) study. Hypertens Res 2010; 33: 1150-1154

263 Lanzani C, Citterio L, Glorioso N, Manunta P, Tripodi G, Salvi E, Carpini SD, Ferrandi M, Messaggio E, Staessen JA, Cusi D, Macciardi F, Argiolas G, Valentini G, Ferrari P, Bianchi G. Adducin- and ouabain-related gene variants predict the antihypertensive activity of rostafuroxin, part 2: clinical studies. Sci Trans/ Med 2010; 2: 59-87.

264 van Zwieten PA, Thoolen MJ, Timmermans PB. The hypotensive activity and side effects of methyldopa, clonidine, and guanfacine. Hypertension 1984; 6: II-28-II-33.

265 Fenton C, Keating GM, Lyseng-Williamson KA. Moxonidine: a review of its use in essential hypertension. Drugs 2006; 66: 477-496.

266 Colucci WS. Alpha-adrenergic receptor blockade with prazosin. Consideration of hypertension, heart failure, and potential new applications. Ann Intern Med 1982; 97: 67-77.

267 Davey MJ. Alpha adrenoceptors-an overview. J Mol Cell Cardiol 1986; 18: S1-S15.

268 Takahashi H, Okabayashi H, Suga K, Matsuzawa M, Ikegaki I, Yoshimura M. Sympatholytic effects of the intravenously injected alpha 1-adrenergic blocker, bunazosin, in anaesthetized rats. J Hypertens 1987; 5: 677-682.

269 Yoshioka M, Togashi H, Abe M, Ikeda T, Matsumoto M, Saito H. Central sympathoinhibitory action of alpha-1 adrenoceptor antagonist, YM-617, in rats. J Pharmcol Exp Ther 1990; 253: 427-431.

270 Pool J, Kaihlanen P, Lewis G, Ginsberg D, Oparil S, Glazer R, Messerli FH. Once-daily treatment of patients with hypertension: a placebo-controlled study of amlodipine and benazepril vs amlodipine or benazepril alone. J Hum Hypertens 2001; 15: 495-498.

271 Brown MJ, Toal CB. Formulation of long-acting nifedipine tablets influences the heart rate and sympathetic nervous system response in hypertensive patients. $\mathrm{Br} J \mathrm{Clin}$ Pharmacol 2008; 65: 646-652.

272 Ram CV, Featherston WE. Calcium antagonists in the treatment of hypertension. An overview. Chest 1988; 93: 1251-1253.

273 Noll G, Wenzel RR, Shaw S, Lüscher TF. Calcium antagonists and sympathetic nerve activation: are there differences between classes? J Hypertens 1998; 16: S17-S24.

274 Furberg CD, Psaty BM, Meyer JV. Nifedipine. Dose-related increase in mortality in patients with coronary heart disease. Circulation 1995; 92: 1326-1331.

275 Huang BS, Murzenok PP, Leenen FH. Sympathoinhibitory and depressor responses to long-term infusion of nifedipine in spontaneously hypertensive rats on high-salt diet. $J$ Cardiovasc Pharmacol 2000; 36: 704-710.

276 Leenen FH, Ruzicka M, Huang BS. Central sympathoinhibitory effects of calcium channel blockers. Curr Hypertens Rep 2001; 3: 314-321.

277 Iyoda I, Takahashi H, Takeda K, Inoue A, Yoneda S, Sasaki S, Okajima H, Yoshimura $\mathrm{M}$, ljichi $\mathrm{H}$. Centrally-induced vasodepressor responses to diltiazem, a calcium channel blocker, in rats. J Hypertens 1985; 3: 639-644.

278 Huang BS, Murzenok PP, Leenen FH. Sympathoinhibitory and depressor responses to long-term infusion of nifedipine in spontaneously hypertensive rats on high-salt diet. $J$ Cardiovasc Pharmacol 2000; 36: 704-710.

279 Srivastava RK, Kulshrestha VK, Singh N, Bhargava KP. Central cardiovascular effects of intracerebroventricular propranolol. Eur J Pharmacol 1973; 21: 222-229.

280 Reid JL, Lewis PJ, Myers MG, Dollery CT. Cardiovascular effects of intracerebroventricular d-, I- and dl-propranolol in the conscious rabbit. J Pharmacol Exp Ther 1974; 188: 394-399.

281 Myers MG, Lewis PJ, Reid JL, Dollery CT. Brain concentration of propranolol in relation to hypotensive effect in the rabbit with observations on brain propranolol levels in man. J Pharmacol Exp Ther 1975; 192: 327-335.
282 Gerstberger R, Müller AR, Simon-Oppermann C. Functional hypothalamic angiotensin II and catecholamine receptor systems inside and outside the blood-brain barrier. Prog Brain Res 1992; 91: 423-433.

283 Johnson AK, Gross PM. Sensory circumventricular organs and brain homeostatic pathways. FASEB J 1993; 7: 678-686.

284 McKinley MJ, Allen AM, Burns P, Colvill LM, Oldfield BJ. Interaction of circulating hormones with the brain: the roles of the subfornical organ and the organum vasculosum of the lamina terminalis. Clin Exp Pharmacol Physiol 1998; 25: S61-S67.

285 Bealer SL, Metcalf CS, Heyborne R. Increased dietary sodium alters Fos expression in the lamina terminalis during intravenous angiotensin II infusion. Exp Neurol 2007; 204: 299-306.

286 Krause EG, Melhorn SJ, Davis JF, Scott KA, Ma LY, de Kloet AD, Benoit SC, Woods SC, Sakai RR. Angiotensin type 1 receptors in the subfornical organ mediate the drinking and hypothalamic-pituitary-adrenal response to systemic isoproterenol. Endocrinology 2008; 149: 6416-6424.

287 Duvernoy HM, Risold PY. The circumventricular organs: an atlas of comparative anatomy and vascularization. Brain Res Rev 2007; 56: 119-147.

288 Buggy J, Fink GD, Johnson AK, Brody MJ. Prevention of the development of renal hypertension by anteroventral third ventricular tissue lesions. Circ Res 1977; 40: I110-I-117.

289 Pamnani MB, Buggy J, Huot SJ, Haddy FJ. Studies on the role of a humoral sodiumtransport inhibitor and the anteroventral third ventricle (AV3V) in experimental lowrenin hypertension. Clin Sci (Lond) 1981; 61: 57s-60s.

290 Haywood JR, Fink GD, Buggy J, Boutelle S, Johnson AK, Brody MJ. Prevention of twokidney, one-clip renal hypertension in rat by ablation of AV3V tissue. Am J Physiol 1983; 245: H683-H689.

291 Songu-Mize E, Bealer SL, Caldwell RW. Effect of AV3V lesions on development of DOCA-salt hypertension and vascular Na+-pump activity. Hypertension 1982; 4: 575-580.

292 Goto A, Ganguli M, Tobian L, Johnson MA, Iwai J. Effect of an anteroventral third ventricle lesion on $\mathrm{NaCl}$ hypertension in Dahl salt-sensitive rats. Am J Physiol 1982; 243: H614-H618.

293 Gordon FJ, Haywood JR, Brody MJ, Johnson AK. Effect of lesions of the anteroventral third ventricle (AV3V) on the development of hypertension in spontaneously hypertensive rats. Hypertension 1982; 4: 387-393.

294 Ogihara T, Kikuchi K, Matsuoka H, Fujita T, Higaki J, Horiuchi M, Imai Y, Imaizumi T, Ito S, Iwao H, Kario K, Kawano Y, Kim-Mitsuyama S, Kimura G, Matsubara H, Matsuura H, Naruse M, Saito I, Shimada K, Shimamoto K, Suzuki H, Takishita S, Tanahashi N, Tsuchihashi T, Uchiyama M, Ueda S, Ueshima H, Umemura S, Ishimitsu $\mathrm{T}$, Rakugi $\mathrm{H}$. The Japanese Society of Hypertension guidelines for the management of hypertension (JSH 2009). Hypertens Res 2009; 32: 3-107.

295 Chobanian AV, Bakris GL, Black HR, Cushman WC, Green LA, Izzo Jr JL, Jones DW, Materson BJ, Oparil S, Wright Jr JT, Roccella EJ. The seventh report of the joint national committee on prevention, detection, evaluation, and treatment of high blood pressure: the JNC 7 report. JAMA 2003; 289: 2560-2572.

296 Grassi G. Sympathetic neural activity in hypertension and related diseases. Am J Hypertens 2010; 23: 1052-1060.

This work is licensed under the Creative Commons Attribution-NonCommercial-No Derivative Works 3.0 Unported License. To view a copy of this license, visit http://creative commons.org/licenses/by-nc-nd/3.0 